Title:

\title{
Consolidating the current knowledge on urban agriculture in productive urban food systems: learnings, gaps and outlook
}

\section{Author names and affiliations:}

Till Weidner ${ }^{\mathrm{a}}$, Aidong Yang ${ }^{\mathrm{a}}$ and Michael W. Hamm ${ }^{\mathrm{b}}$

aUniversity of Oxford, Department of Engineering Sciences, Parks Road, Oxford OX1 3PJ, United

Kingdom,

${ }^{b}$ Michigan State University, Dept. of Community Sustainability, Natural Resources Building, 480

Wilson Road, Rm 312B, MSU, East Lansing, MI 48824, United States

till.weidner@eng.ox.ac.uk

aidong.yang@eng.ox.ac.uk

mhamm@anr.msu.edu

\section{Corresponding author:}

Aidong Yang, University of Oxford, Department of Engineering Sciences, Parks Road, Oxford OX1 3PJ, United Kingdom, aidong.yang@eng.ox.ac.uk

\section{Abstract}

Urban agriculture is of increasing interest for tackling a range of environmental and social issues of the current food systems. However, many questions remain unanswered regarding upscaling, the balancing of its multipurpose nature, and how it should be embedded into the broader urban system. This review looks at a breadth of novel insights that are indicative for sensible future development, including new possibilities for nutrient circularity, opportunities for increased sustainability and open questions regarding logistics and economics and development pathways. A thorough assessment of the existing self-sufficiency studies is provided to advance the debate on expected productivity, which is highly dependent on the intended outcomes and the choice of practices employed. Addressing resource circularity, decentralized anaerobic digestion and vermicomposting are presented as methods of utilizing organic waste in urban agriculture, in particular food and garden waste. Furthermore, critical aspects of sustainability are synthesized and promising developments, such as the co-location of micro-scale anaerobic digestion and greenhouses, are evaluated and research gaps regarding life cycle analysis and technical understanding identified. The review also identifies three aspects of urban agriculture upscaling that have not been well studied, namely logistics, economic performance and business models, and institutional and civil development. Finally, the realization of the transformative potential of urban agriculture based on industrial ecology and inclusive co-design is discussed.

\section{Highlights}

- Existing self-sufficiency studies exhibit greatly varying outcomes

- Novel pathways of utilizing urban organic waste in resilient hydroponics

- Improved sustainability by integration with buildings and waste conversion sites

- Need for further study of logistics, economics and policy measures

- Making UA truly transformative requires inclusive and environmentally considerate scaling up 
Literature Review

Consolidating the current knowledge on urban agriculture in productive urban food systems: learnings, gaps and outlook

1. 3

1.13

1.24

1.34

1.45

2. 5

2.15

$2.2 \quad 7$

2.2.1. 9

2.2.2. 10

2.2.3. $\quad 10$

$2.3 \quad 11$

$2.4 \quad 13$

$2.5 \quad 15$

3. 19

$3.1 \quad 19$

$3.2 \quad 20$

$3.3 \quad 22$

4. 24

\footnotetext{
Abbreviations

$A D=$ anaerobic digestion

$\mathrm{CEA}=$ controlled environment agriculture

CSA = community supported agriculture

LIDAR = light detection and ranging

PUFS = productive urban food systems

$\mathrm{UA}=$ urban agriculture
} 


\section{Introduction}

\subsection{The context of urban agriculture as part of productive urban food systems}

Increasing urbanization, population growth, deteriorating soil and extreme climate events put pressure on global food security, while a third of the global population suffers from malnutrition, through either obesity, food insufficiency, or nutrient deficiency (UNICEF, 2016; UNCCD, 2017). Additionally, the current food system contributes heavily to our global environmental challenges including biodiversity loss, climate change, fresh water pollution, deforestation, and excess nutrient accumulation (Jaramillo \& Destouni, 2015; Lenka, Lenka, Sejian, \& Mohanty, 2015). Innovation, dietary pattern change, and rethinking the direction of our global food system are therefore imperative in the $21^{\text {st }}$ century (Tilman and Clark, 2014).

Producing food within urban boundaries has been suggested as a way to simultaneously tackle a breadth of environmental, social, and human health issues. Research has shown that in addition to achieving a certain degree of self-sufficiency (Clinton et al., 2018), potential climate change mitigation (Kulak et al., 2013) and ecosystem benefits (Wilhelm \& Smith, 2017), urban agriculture (UA) has the potential to increase resource efficiency and circularity (Mohareb et al., 2017), foster social development and community cohesion (Duchemin et al., 2008), and broaden biosphere (Lin et al., 2015) and dietary diversity (Wilkins et al., 2015).

Urban agriculture as a primary production process can be viewed as a component embedded in the urban food system, which further includes processing, packaging, distribution and retail. These closely interact with urban material and resource streams such as water, energy, and organic waste. The practice of UA also entails various institutional norms, government and private sector policies, and cultural attributes in any city region. Here, the term 'productive urban food systems' (PUFS) is used in this work to account for the range of productive activities within the urban boundaries (excluding peri-urban or non-urban local agriculture), the required logistics, and all the related material and other resource flows as well as the social components.

This review has been produced in light of a multitude of recent studies and urban trends that illustrate a way UA could be understood to maximize its benefit to society and environment. In addition, this review endeavors to address: (i) the debate about self-sufficiency with a detailed overview of relevant estimations and their methodologies, (ii) the most recent knowledge of nutrient circularity opportunities and critical sustainability metrics, (iii) empirical research requirements for holistically understanding and propelling PUFS and (iv) the current knowledge of guiding principles about scaling up in a socially and environmentally inclusive way. We believe a particular focus on these elements is warranted in order to shed light on needs for future research and practices on UA.

Other important elements and the general development of UA have already been reviewed in the last several years and are not directly included in this work. Mok et al. (2014) examined the state of UA in the developed world, while Orsini, Kahane, Nono-Womdim, \& Gianquinto (2013) investigated several development factors required for UA. The current state of global rooftop greenhouse projects was reviewed by Buehler \& Junge (2016) and Proksch (2011) summarized the multifold benefits and technicalities of productive green roofs. Specht et al. (2014) reviewed existing literature regarding environmental, social, and economic dimensions. Mohareb et al. (2017) reviewed studies on the potential integration with urban resource flows, such as greywater and waste heat, embedding UA into the broader food system and the food-energy-water nexus. Literature reviews exist also on ecosystem services, such as storm water attenuation and biodiversity (Lin et al., 2015), as well as disservices, such as run-off pollution (Russo et al., 2017). The academic discourse on the climate innovation potential of different UA typologies (e.g. water retention, urban heat island effect, energy consumption, inputs, all by topology) as well as their potential for global climate mitigation has been reviewed Koegler et al. (2017). 
This review considers mainly activities in the Global North for several reasons. The study and quantification of UA practices in the developing world is only loosely defined (Ellis and Sumberg, 1998). Even though there is considerable urban farming activity (Hamilton et al., 2014), Martellozzo et al. (2014) have found the potential for self-sufficiency for most of the developing countries with their densely populated cities to be rather small. The lack of available urban data in the developing world makes accurate spatial analysis and planning difficult. Nevertheless, findings and outlooks from reviewing the development in the Global North could be transferred to other geographies with appropriate consideration of place differences.

\subsection{Realistic lens: Advocacy and opposition}

Until recently, UA has been used as an all-encompassing term for different practices and strategies, which has attracted both optimistic and pessimistic views.

Research on UA has generally tended to take an advocacy viewpoint (Neilson and Rickards, 2017), which might have led to overstating its potential in some cases, in turn attracting criticism. Badami \& Ramankutty (2015) found that the contribution of UA to the food security of the urban poor is quite low, despite the strongest need. A study of community growing practices led the authors to conclude that UA can "produce little more than "nibbles" (Martin et al., 2014). However, these studies look at self-sufficiency for the whole food basket (i.e. including meat and cereal) based on low-yield methods - which is clearly unattainable - and necessitates studies on self-sufficiency in terms of certain types of produce only, such as fruits and vegetables.

A similar narrative is observed for the promises of increased sustainability, where benefits offered by some particular growing practices seem to have been applied to the whole spectrum of UA. An early report by Mougeot (2000) provided a balanced picture of environmental benefits and risks pertaining to UA. However, these environmental risks or challenges have been mostly overlooked, leading to critical research gaps (Wortman and Lovell, 2013). Russo, Escobedo, Cirella, \& Zerbe (2017) reviewed the most relevant studies that investigated positive ecosystem services - such as biodiversity and storm water attenuation - and negative ecosystem disservices - such as contaminated run-off and gaseous emissions - with 146 versus 52 papers respectively. A case-specific challenge to the general sustainability claim came from Goldstein, Hauschild, Fernández, \& Birkved (2016a) who employed Life Cycle Analysis (LCA) and found that the highyield growing practices which significantly increase self-sufficiency have a worse impact on the environment than conventional agriculture. Furthermore, controlled environment UA likely does not provide other often associated ecosystem benefits, e.g. increased biodiversity and reduction of the urban heat island effect.

Due to the stark differences of outcome and impact, it seems obligatory in further scientific discourse to specify the growing techniques and operational modes employed when suggesting the benefits and potential drawbacks of UA.

\subsection{Efforts to define and classify}

To cope with the differing production capacity and socioecological impacts, growing practices for UA have been defined and classified depending on the paradigm of interest. Goldstein, Hauschild, Fernández, \& Birkved (2016b) classified practices depending on their location (ground based or building integrated) and the extent of controlling the growing environment (conditioned and non-conditioned) and characterized the four resulting classifications by their operational characteristics, capital inputs and potential for urban symbiosis. Koegler, Jean-Paul, \& Aubry (2017) further sub-divided these four categories depending on their economic model and size (ground based) and technological sophistication and access to sunlight (building integrated), and showed their potential regarding climate change adaptation and mitigation.

A more socioeconomic approach has been employed by looking at different motivational frames (sustainable development, radical, DIY secessionist, educational, eco-centric, entrepreneurial), their funding sources and 
consequences, thus allowing more intention-matching policy making and support (McClintock and Simpson, 2017). Another study grouped practices by their produce distribution level, the actors involved and the main interest (self-supply, commercial, social-cultural), concluding that diversity of types ensures multifunctionality and policy should not favor one over the other (Krikser et al., 2016). Thomaier et al. (2015) created a typology for vertical farming practices (image-oriented, living quality, commercial, social and educational, innovation incubator) depending on their market orientation and transformative potential.

\subsection{Methodology}

The studies mentioned in this review have been selected through keyword searches in Google Scholar in December 2017 and again in February and April 2018. The following terms were searched individually and in combinations of up to 3 terms:

- Aquaponics, economics, energy efficiency, fish feed, food waste anaerobic digestion, food waste digestate, GIS, hydroponics, insects, integrated greenhouse, LCA, micro-scale anaerobic digestion, nutrient circularity, organic agriculture, organic waste management, organic waste valorization, policy, resource circularity, rooftop greenhouse, spatial analysis, stakeholder (perception / participation), sustainability, sustainable, urban agriculture, urban farming, urban food-energy-water nexus, urban food systems, urban horticulture, urban self-sufficiency, vermicomposting, vertical farming.

Titles of over 500 papers were scanned and over 300 papers were screened before 145 relevant scientific publications were eventually selected for this review. Studies were screened if they either:

(i) reviewed the current state of urban agriculture or aspects of it;

(ii) contained research and findings that were not typically found in other reviews;

(iii) conducted studies on emerging topics such as organic hydroponics, waste valorization, nutrient circularity, or food waste digestate use in agriculture;

(iv) combinations and integrations of current technologies and practices;

(v) looked at the broader picture of urban food production such as logistics, economics, environmental impacts, implementation and policy.

Additional studies were found by investigating the references and "cited by" of the most relevant papers and authors, scanning Researchgate for reports and recommendations and the "literature suggestion" function of Mendeley.

The literature included peer-reviewed articles, books, conference proceedings, personal communications with researchers in this area and commercial websites if the technology was relatively new and not yet researched well. Hence, this paper includes a few references to commercial products to show developments in the respective areas; the authors do not endorse the products or attest to the veracity of their analysis. Although part of the urban food system, urban beekeeping is not addressed.

\section{Consolidation of current knowledge and approaches}

\subsection{Nutrients versus calories}

An important metric for quantifying the self-sufficiency potential of UA is the choice of food items intended to supply. Existing studies have assumed different selections of food types, including animal products, cereals, oils and the more common fruits and vegetables. Martellozzo et al. (2014) compared an estimation for the area required to satisfy global cereal (661.6 Mha) and vegetable (47.2 Mha) demand with the global urban land area (64.3 Mha), which indicates that it is unrealistic to expect UA to provide the calories (and protein) required for a human diet. The authors furthermore shed light on the properties of micronutrientrich foods (i.e. fruits and vegetables) as high-yield, high-value, perishable and a major indicator of dietary 
diversity - potentially fitting for the limited amount of land in cities and the potentially very short supply chains. A separate study estimating the global land requirements arrived at the same conclusion, highlighting the non-perishable nature of most cereal crops ( 700 Mha currently cultivated) versus the dietary diversity-inducing nature of vegetables ( 60 Mha currently cultivated)(Badami and Ramankutty, 2015).

Other considerations are the labor intensity and urban suitability of different food types. Horticulture, in part the practice of growing vegetables and fruits (within the discipline things like flower production are also considered 'horticulture'), typically uses much less mechanization, resulting in 20 times more man-hours per hectare farm land than cereal production (Devlin, 2016). Clinton et al. (2018) ranked food crops by ease of growing and nutrient density, dismissing exotic fruit trees, process-intensive seed crops and non-food consumables as viable options for UA in the Global North.

Table 1: Differences between agriculture and horticulture in relation to urban growing

\begin{tabular}{lcc} 
Aspect & Agriculture & Horticulture \\
\hline Provision & Calories/Protein & Micro nutrients \\
Examples & Grains, potatoes, legumes & Fruits, vegetables \\
Area required $^{1}$ & $1029 \%$ of urban space & $73 \%$ of urban space \\
Daily amount recommended ${ }^{2}$ & $0.5-1.5 \mathrm{~kg}$ & $0.4 \mathrm{~kg}$ \\
Treatment prior to consumption & Multi-step processing & None or minimal \\
Longevity & Weeks to years & A few days \\
Level of mechanization possible & Very high & Limited but with potential \\
Labor intensity $\left(\right.$ jobs per hectare) $^{3}$ & 0.02 & 0.23 \\
Yield $^{4}$ & $\sim 0.5-5 \mathrm{~kg} / \mathrm{m}^{4}$ & $\sim 5-50 \mathrm{~kg} / \mathrm{m}^{4}$ \\
Average sale value $(\$ / \mathrm{kg})$ & Low to medium & Medium to high
\end{tabular}

(1) Martellozzo et al. (2014)

(2) WHO (2003)

(3) Devlin (2016)

(4) FAO, (2016)

The authors therefore conclude that the term urban horticulture may be more appropriate to describe the most widespread activities in urban space, while food security and food equity should be understood as (micro-)nutritional equity and security as realistic targets for food produced and distributed within the urban space. However, given that the vast majority of articles cited in this review use the term 'urban agriculture' we will continue to use it - with the understanding that we are talking about fruit and vegetable production - or urban horticulture. Furthermore, as external shocks to the PUFS might cause a loss of harvest or productive capacity (e.g. an earthquake, as studied by Sioen, Sekiyama, Terada, \& Yokohari (2017)) it is 
unlikely to be desirable for cities to be completely detached from global food supply chains for these products.

\subsection{Self-sufficiency estimates and methodologies}

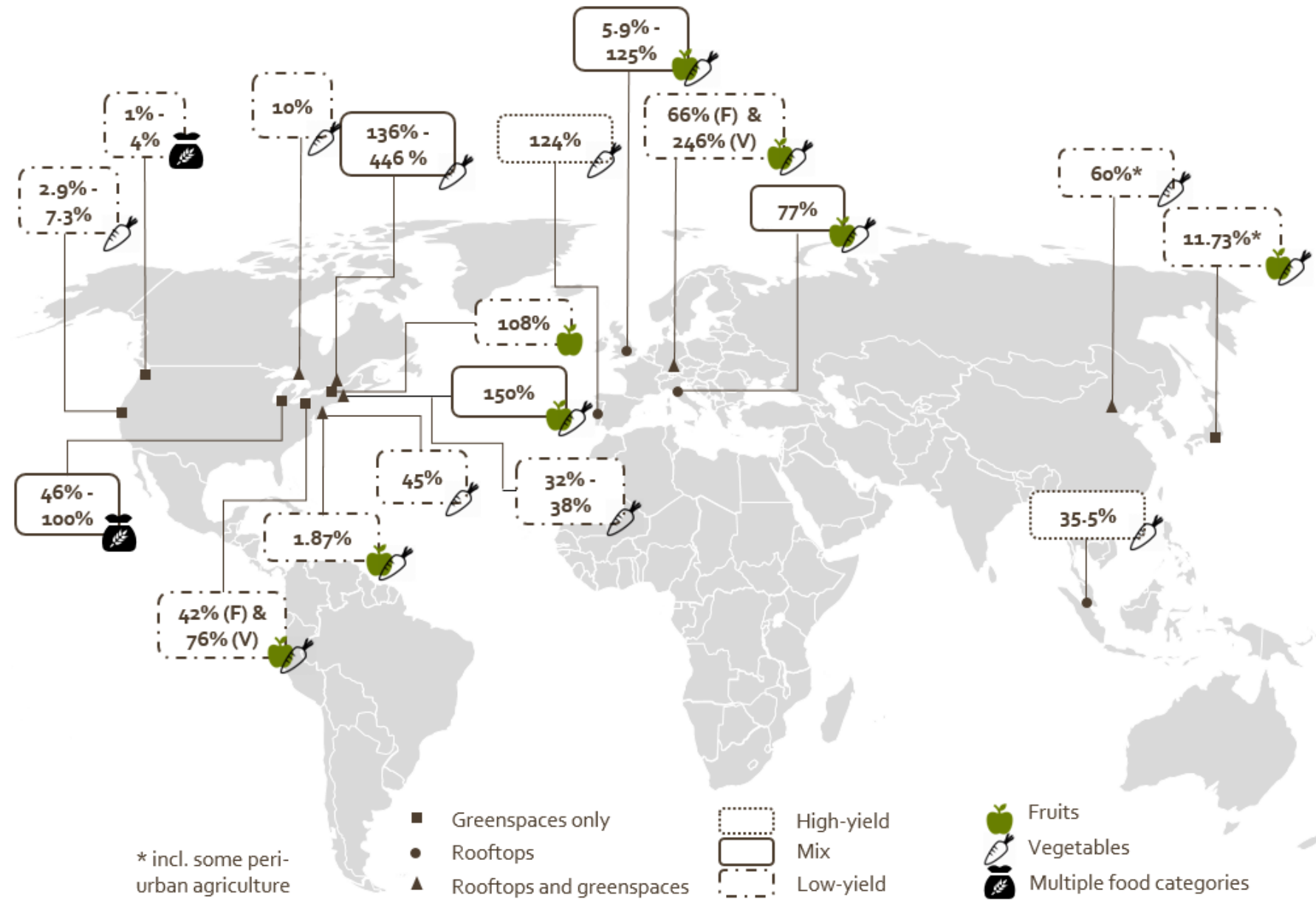

Figure 1: World map of self-sufficiency studies

The desire to estimate how much UA can contribute to satisfying a city's food demand has resulted in a multitude of empirical studies. Figure 1 is an overview of the self-sufficiency studies related to UA, including the percentage of demand satisfaction, the type of growing technique employed (e.g. low-yield open-air growing or high-yield hydroponics growing), and the types of areas (i.e. surfaces for growing) investigated. Every self-sufficiency exercise necessarily contains yield assumptions, growing area estimates, and demand figures. Within a similar latitude the results differ substantially with a very diverse choice of area and growing techniques. Population density of the studies mapped in Figure 1 were used to understand the relationship to self-sufficiency potential. As a potential indirect factor determining how much non-built up space is available, it does not seem to strongly dictate the results, as shown in Figure 2, but a weak correlation exists between decreasing self-sufficiency potential and increasing population density. Scaling up to a higher level of self-sufficiency has economic cost and environmental and social impacts (potentially both positive and negative). Besides, in reality UA has to operate as part of a supply chain and interact with the rest of the urban environment (e.g. increased traffic through food delivery trucks). These broader issues (listed in Table 2) have been considered to varying (but generally rather limited) extents by existing selfsufficiency-oriented studies, and they will be discussed later in this review. 


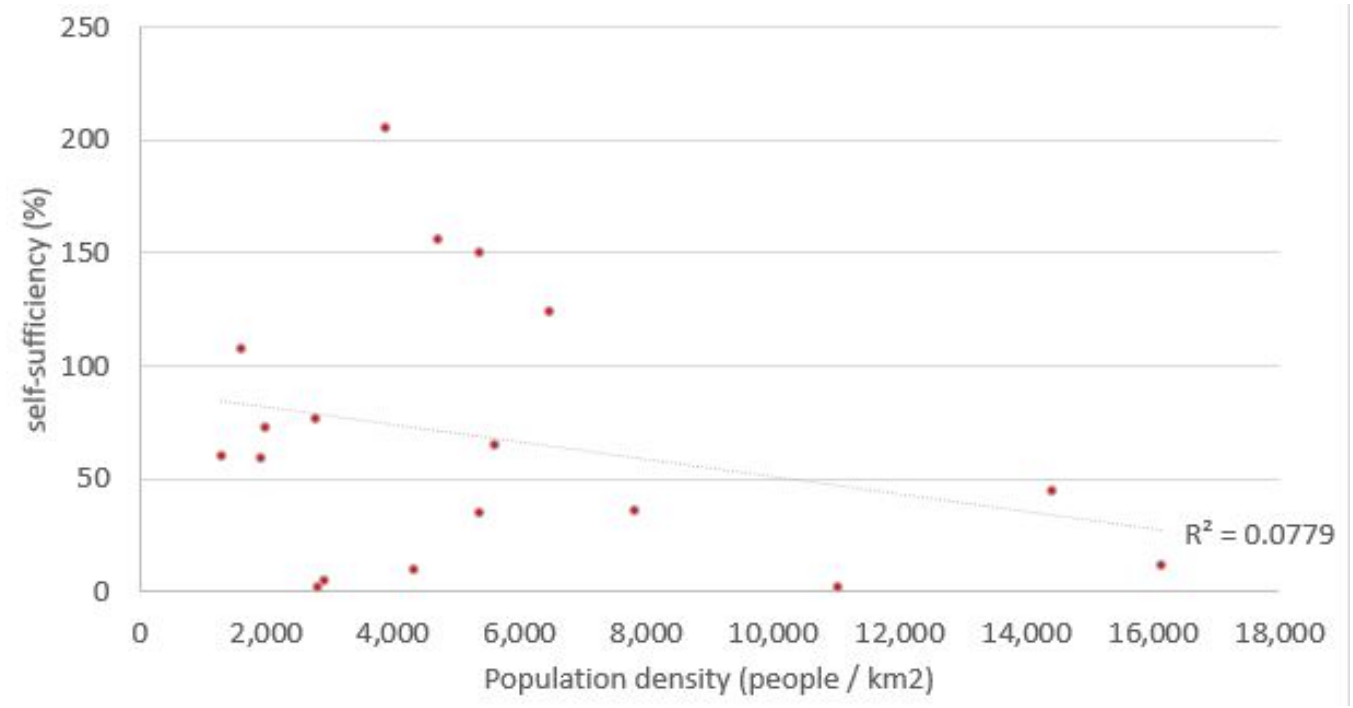

Figure 2: The relation between self-sufficiency and population density of the investigated studies 


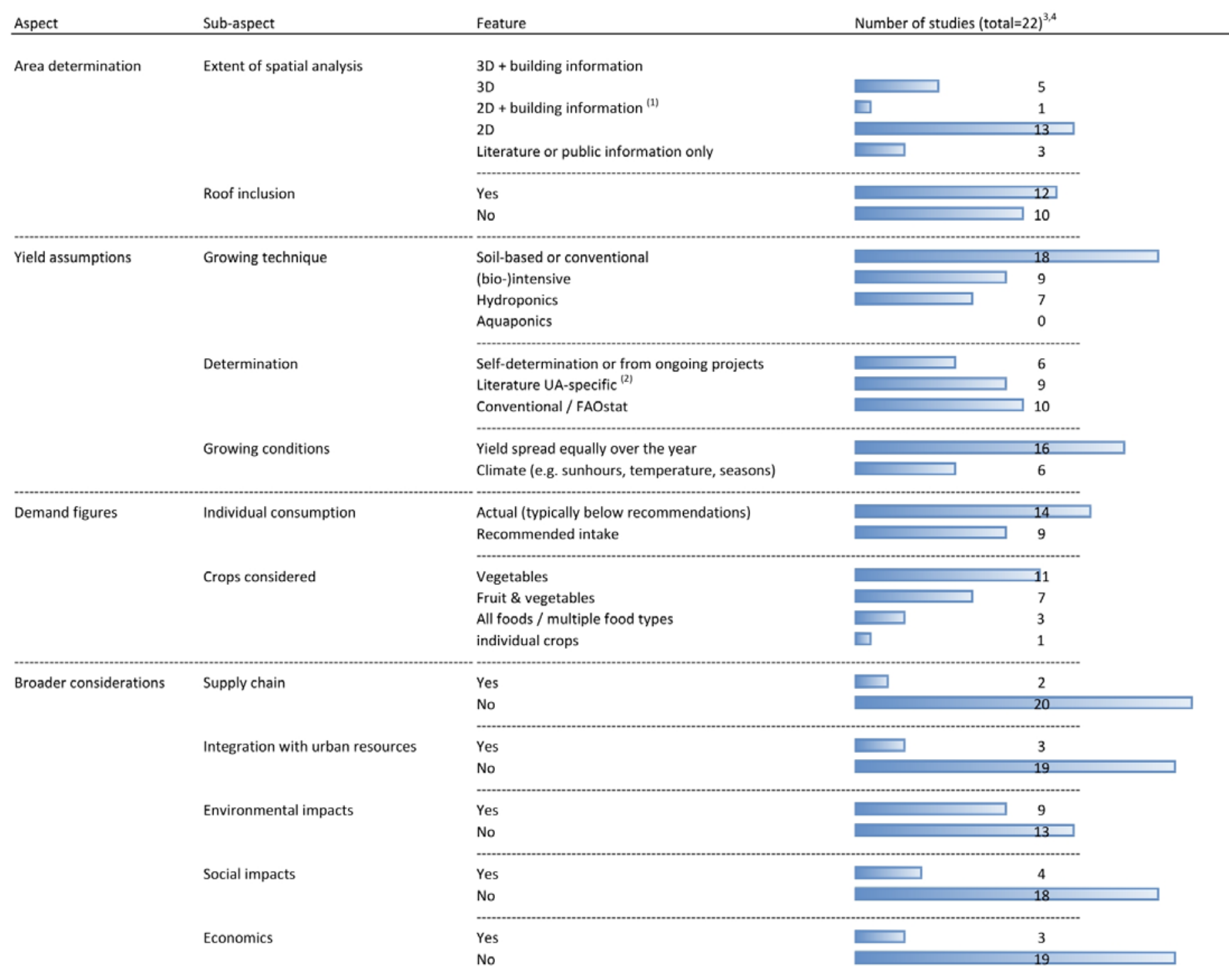

1 Related to rooftop suitability and resource integration, e.g. structural capacity, building year, type of insulation, heat source

2 Derived from other case studies or from urban agriculture repots

3 Global assessments have been excluded in the overview (Figure 1), studies can have multiples entries in some sub-aspects

4 The categorization and references of the self-sufficiency studies are provided in the Supplementary Information

Table 2: Overview of different methodologies applied for the self-sufficiency assessments

\subsubsection{Estimation of area available for growing}

Recent advances in available geospatial (2D) and remotely sensed LiDAR (3D, light detection and ranging) data have facilitated the determination of available growing space in urban areas. The combination of easily manipulatable geospatial data with available information on greenspace usage as well as building type, year, and function can greatly increase the accuracy of the estimation compared to just using public and land survey information (Goldstein, Hauschild, Fernández, \& Birkved, 2017). Despite a lack of a clearly defined methodology for determining greenspace area, the technicalities of employing either geospatial data or satellite imagery to identify suitable spaces have been very similar between various studies. Ultimately, the intended extent of a scaled-up UA system will determine which kinds of greenspace are to be included in the analysis (e.g. vacant lots only vs. also including residential yards, parks and community gardens). When it comes to rooftops, however, different methods have led to quite different outcomes. A study using LiDAR data by Saha \& Eckelman (2017) identified 922 ha of rooftop space in Boston (equivalent to $42 \%$ of total roof 
area), while Goldstein et al. (2017) using tax records and geospatial data, identified for the same city 10.5 ha and 171 ha depending on whether the older buildings are included (equivalent to $0.46 \%$ and $7.8 \%$ of roof spaces). Combining LiDAR data, tax records and individual building information as the most comprehensive compilation of information, Nadal et al. (2017) distilled the amount of available roofspace in a Barcelona district with three different levels of estimates, namely an economically feasible minimum size of $>500 \mathrm{~m}^{2}$ ( $40.4 \%$ remaining), exclusion of shaded roofs ( $15.2 \%$ remaining) and considering only structurally adequate roofs (2.9\% remaining). In light of the results of such detailed studies, some of the rooftop area estimates in other work might have been overstated without considering major retrofits on buildings, alternative uses such as solar and wind energy generation, among other issues. Nevertheless, it is clear that rooftop growing should be included in future assessments and UA-promoting policy.

\subsubsection{Assumptions of crop yields and growing techniques}

Growing practices and yield assumptions

Some studies have used yield figures for soil-based, non-conditioned growing practices only, reported from either UA projects or other literature. Typically, the achieved yield average by community gardening (1.2-2.6 $\left.\mathrm{kg} / \mathrm{m}^{2}\right)$ is below the reported average for horticulture in developed countries $\left(2.5-3.3 \mathrm{~kg} / \mathrm{m}^{2}\right.$, (FAO, 2016)) with only professional and intensive gardening surpassing those yields $\left(5.4-7.1 \mathrm{~kg} / \mathrm{m}^{2}\right)$. Without high-yield growing techniques such as hydroponics or high-density in-ground practices, which allow for higher plant density and/or a more controlled growing environment, it seems to be very challenging to contribute significantly to self-sufficiency (see Figure 1). This is particularly true for cities with high population density and limited greenspaces. While providing a selection of worthwhile socioecological benefits, one could argue that analyses based solely on low-yield practices should not be used when criticizing the low contribution of UA to self-sufficiency. Further studies and policy should therefore clearly state the goal of scaling up UA and include high-yielding growing practices if a relatively high degree of self-sufficiency is desired.

ii) Underrepresentation of thoroughly evaluated high-yield figures

The range of employed yield figures for hydroponic practices is quite large (from $1.1 \mathrm{~kg} / \mathrm{m}^{2}$ (Orsini et al., 2014) to $76 \mathrm{~kg} / \mathrm{m}^{2}$ (Benis, Reinhart, \& Ferrão, 2017b)). Only a few studies employ either self-determined or commercially established figures. As the resulting self-sufficiency and some sustainability metrics depend so strongly on the yield, future studies are recommended to draw yield data from the numerous commercial projects, realistic simulations, or ongoing research.

iii) Consideration of harvest season versus year-round demand

Most studies have considered annual yield figures. It would be an over-simplification if such figures imply that the produce is provided all year long. In reality, many types of produce are likely to be harvested over the course of a few months only, requiring cold storage if the supply is equally spread over the year and consequently more space and energy requirements. Using a more nuanced approach, Colasanti \& Hamm (2010) gave an indication of storage requirements and differences in expected annual produce when hoop houses are employed to extend the growing season. To understand the quantity of produce available at any given day in the year, Sioen, Terada, Sekiyama, \& Yokohari (2018) utilized a harvest map to evaluate the degree of self-sufficiency in the face of a system shock. In general, current studies on urban horticulture provisioning typically suffer from limitations including a lack of consideration of seasonality, the exclusion of storage or preservation considerations, and a lack of differentiation between year-long conditioned and season dependent growing practices.

\subsubsection{Assumptions for demand}


Assessments of the demand as a combination of the crops considered and the assumed daily consumption, as well as the available growing area are also required (see Table 2). The existing studies differ significantly in their methods; hence results should be treated individually. Most of the studies that focus on a limited number of specific crops have still assumed satisfying the complete amount of recommended or actual fruit $\&$ vegetable intake. It is unlikely and potentially undesired to reduce the dietary diversity of consumers. Nevertheless, generalization can serve as simplification if similar yield figures between crops are to be expected - which is often not the case however.

\subsection{New possibilities for increased urban nutrient circularity}

One potential advantage of UA is the possibility to increase plant nutrient circularity as well as providing a positive strategy for organic waste usage. This section looks at emerging trends in the utilization of urban organic waste streams with the potential to be incorporated into PUFS for increased sustainability and nutrient cycling.

i) Organic waste streams and circular potentials with current technologies

As potential resources for UA, waste water and organic solid waste (e.g. food waste, yard trimmings) can be converted into compost, biogas, and fertilizer (Mohareb et al., 2017). In waste water, important nutrients for plant growth, such as phosphorus from human waste and detergents, are lost to the sewage system (Gilmour et al., 2008). Despite the typical recovery in activated sludge, it can rarely be used in UA due to problems with heavy metals, pathogens and residues of pharmaceuticals or recreational drugs (Kinney et al., 2006). Currently, there are two possible solutions to this: (i) source separation and decentralized treatment and (ii) phosphorus recovery from sewage sludge ash. The former is usually limited by the requirements of newly built infrastructure as it employs separate piping, vacuum toilets and membrane bioreactors. This has been demonstrated in a pilot study for a Hamburg district (Hertel et al., 2015) and Qingdao (Tolksdorf et al., 2016). The latter is limited by cost and recovery efficiency (Egle et al., 2016). A mix of the methods in combination with UA has been studied for the city of Rotterdam (Wielemaker et al., 2018). At present, neither of these options represents a ready-to-implement, scalable solution that allows cities to use waste water to fertilize plants and condition soil.

Other organic waste usually ends up in the municipal solid waste (MSW) or, if separated, in compost and/or anaerobic digestion. If organic waste is separated from MSW after collection, it typically exhibits high concentrations of heavy metals, making it unsuitable for reuse in UA (Alvarenga et al., 2015). Again, the most opportune pathway is source separation at the household and industry level, for which some cities have shown considerable success. For example, composting is mandatory in San Francisco since 2009 and every day around 650 tons of collected compostable material (of which one half is food scraps and the other yard trimmings) are turned into 350 tons of finished compost (NRDC, 2017), recovering roughly $0.4 \mathrm{~kg} / \mathrm{day} /$ person of food waste. In the city of Oxford, a household composting bin is provided and, despite composting not being mandatory, they collect around $0.2 \mathrm{~kg} /$ day/person of source-separated organic waste (OCC, personal communication, May 3, 2018). As this presents a significant untapped resource, the following two sections consider how source separation and collection present a substantial opportunity when combined with new developments in UA practices.

ii) (Vermi-)composting and decentralized anaerobic digestion

Decomposition of organic matter, e.g. via the guts of earthworms in soil or in an oxygen-depleted environment through bacteria (anaerobic digestion, $A D$ ), is a naturally occurring process. Of interest here is the technical utilization of those techniques to speed up the natural composting process. Vermicomposting promises an effective and fast, one-step organic waste treatment of different types of feedstock with the potential to remediate pollutants and conserve fertilizing minerals (Singh and Singh, 2017). It has been used 
to produce soil conditioner in Cuba for many years, and the humic substances generated improve plant growth performance and metabolism as well as plant defenses (Hernandez et al., 2014). Compared to conventional potting soil, vermicompost as a planting base can cause an increase in yield while preventing heavy metals enrichment in plants (Grard et al., 2015). This has resulted in commercial products for on-site waste conversion, such as institutional vermicomposting pods (www.wormwigwam.com) and screw-driven community-sized units (http://www.kompost.co.uk) that produce compost daily.

Another development is micro-scale AD units located closely to community gardens, exhibiting similar efficiencies as large units (Walker et al., 2017). Food and garden waste is taken from the community to produce biogas (for heating) as well as digestate, which is further processed to fertilizer used in the same garden. A novel digeponic system, consisting of a bubble-insulated greenhouse and integrated AD and vermicomposting units, combines all these ideas (Stoknes et al., 2016). The biogas is used for greenhouse heating and $\mathrm{CO}_{2}$ supply while the digestate is separated into the solid part for substrate production and the liquid part for fertilizer use. Less sophisticated small-scale AD units for urban gardeners are also commercially sold (https://homebiogas.com). Aerobic conversion technologies, which instead of producing biogas reduce the volume of food waste substantially while producing soil conditioner (www.garbageguzzler.com) are also becoming commercially available.

iii) Use of digestate and vermicompost in soil-based and soil-less systems

The accessibility of nutrients, a suitable $\mathrm{pH}$-value, the absence of pathogens and contaminants, and in the case of hydroponics, a liquid product without slime or solids are fertilizer properties required for good operational performance (Jones, Jr. 2004). The quality and composition of digestate is highly feedstock dependent and as previously discussed, sewage sludge or slurry is currently prohibited from agricultural use. Spreading manure digestate on fields has historically been used in rural areas to increase crop yield (Garfí et al., 2011). Dimambro (2016) evaluated digestate produced by different feedstocks with food waste yielding digestate with the highest nitrogen content. However, Neal \& Wilkie (2014) investigated its use in hydroponic tomato production and found that the digestate's high ammonium concentration is harmful to the plants. A review of digestate use in horticulture globally had a similar finding: digestate needs some form of treatment, including a nitrifying step, before becoming beneficial in soil-less culture (Rayns, 2015). Nevertheless, the review concluded that it has significant potential to reduce unsustainable peat substrate use in horticulture (solid fraction) and inorganic fertilizer requirements (liquid fraction).

The problem may be solved in different ways. A process called multiple parallel mineralization (Shinohara et al. (2011)) employs a hydroponic system that has been inoculated with organic matter containing typical soil bacteria. When digestate is added, the ammonium and organic nitrogen is converted in vitro to mineral nitrogen available to the plants. Based on the same idea Kawamura-Aoyama, Fujiwara, Shinohara, \& Takano (2014) added filtered food waste directly to such microbial solutions and observed successful lettuce growth as well as denitrification, an indicator of the presence of nitrate. A slightly different route was taken by the previously mentioned digeponic system, in which the digestate is circulated through an aerated biofilter buffer tank and a vermicompost substrate with earthworms (Stoknes et al., 2016). A separated solid part of the digestate was converted via mushrooms to plant growth substrate, indicating a potential pathway to tackling the peat substrate issue. Also applying digestate filtering with vermicompost and wood chips, a community garden project has produced a ready-to-use liquid product that contains accessible nitrogen and phosphorus (Community by Design, Personal Communication, June 7th 2018). The mixing of vermicompost and worm castings with water and growth nutrients (e.g. molasse) results in "(vermi-)compost tea" after a 24-hour inoculation followed by filtering. This microbial tea has been successfully applied as fertilizer in a hydroponic lettuce growth system, in which a mix of coconut coir and worm castings served as substrate (Baltzell, 2011). Commercial brewing units are available and a specific nutrient mix to aid in bacteria multiplication is claimed to produce a consistent product (http://www.composttea.com). The production, science and benefits of vermicompost teas have been compiled in Edwards et al. (2010). 
These "organic" systems may be able to close the nutrient cycle between urban organic solid waste and fertilizer input, however, their performance versus conventional systems is a crucial indicator for whether they potentially present a scalable solution. The exact relationship between potential nutrient provisioning via a city's organic waste and the needs for food production of a certain amount is yet to be determined with further research warranted.

\section{iv) Performance and resilience of organic growing systems}

Organic versus conventional agriculture on rural farmland is a topic of debate, with organic agriculture promising reduced emissions, pesticide use, and nutrient run-off, while requiring around $33 \%$ more land, in turn potentially causing deforestation and other unsustainable land use change (Adrian Muller et al., 2017). The more contained soil-less systems with effluent filtration cause no nutrient run-off and use inherently less land due to the high yield. However, they typically employ mineral fertilizer, pesticides and other inputs to achieve high yields and control of the production process, all of which emit large amounts of greenhouse gases during production and cause depletion of minerals, including phosphorus, as well as other potential environmental and health impacts (Hamm et al., 2018). Research has been conducted to evaluate whether certain waste products or other organic products can be applied in hydroponic systems. A similar performance to conventional fertilizers was achieved by using poultry digestate in hydroponic lettuce production (Liedl et al., 2004). In another study (Shinohara et al., 2011), inoculated organic fertilizers, one fish-based and one corn-based, resulted in higher yield than conventional fertilizers and strongly increased root hair growth. Some current commercial organic hydroponic farms employ fish-based fertilizers, oyster shell-lime and ash of coconut shell reportedly without experiencing any operational issues (NARO, personal communication, February 2, 2018). In addition, new seaweed derived products are being commercialized (Hortifeeds, personal communication, April 26, 2018). Purely based on food and garden waste, Stoknes et al. (2016) achieved a higher yield with the digeponic fertilizer than with mineral fertilizers ( $9 \%$ more for lettuce, $230 \%$ for cucumber, $10 \%$ for tomato and $207 \%$ for parsley).

A possible reason for the good performance of the organic systems is the emulation of soil microorganisms in the solution. Those so-called biostimulants have been reviewed (Tomasi et al. (2014)) and benefits of multi-purpose microorganisms in solution discussed. In part, these may help create root hair growth that act as a rhizosphere, which in turn increases nutrient uptake. This trend has led to commercialization of rhizobacteria spores, e.g. Bacillus amyloliquefacines (ICL (https://icl-sf.com), Omex (www.omex.co.uk)). Besides nutrient uptake, the beneficial bacteria and fungi in hydroponic systems also help control diseases and produce enzymes that act as plant growth-promoters (Lee and Lee, 2015). This increased resilience has been tested by inoculating the solution with bacterial wilt disease (Fujiwara et al., 2012), pathogenic fungi (Fujiwara et al., 2013) and root rot (Chinta et al., 2014) in both conventional and organic systems. In every case, the disease killed the plants in the conventional system while no harm seemed to be caused in the organic system.

Compared to conventional systems that do not rely on nutrients from organic waste products, the operation and control of organic systems is less understood, with potential risks yet to be quantified. For example, one potential hazard of utilizing organic waste streams in urban environments is microplastics that enter the food web, especially from commercial sources (Weithmann et al., 2018). Nevertheless, the results of the existing studies mentioned above are indicative of an opportunity to increase yields and resilience while potentially lowering the environmental footprints of soil-less urban horticulture.

\subsection{Emerging urban agriculture practices beyond fruits and vegetables}

Although this review is primarily concerned with fruit and vegetable production, it is useful to understand other emerging practices of UA that are closely related. All identified self-sufficiency studies (see sections 2.1 
and 2.2) incorporate a multitude of soil-based and soil-less growing techniques that focus on the production of fruit and vegetables. Aquaponics on the other hand represents a different yet popular endeavor, in which denitrifying bacteria convert the ammonium in fish faeces to readily-available nitrate for plant growth in an integrated system, thus co-producing plants and different types of fish. Such systems share similarities with the organic hydroponic systems in which ammonia in digestate needs to be converted.

\section{i) Aquaponics}

The published literature showed that interests in aquaponics have grown greatly in recent years and the trend, supported by numerous new commercial projects and the overcoming of technological hurdles, is likely to continue (Junge et al., 2017). A potential limitation is the ability to sell the fish fresh due to health concerns surrounding fish processing within urban boundaries (Koegler et al., 2017). Despite this, an international survey revealed that the majority of commercial projects will reach profitability within the next few years, selling mainly on-farm or at farmer's markets (Love et al., 2015). Further studies on assessing selfsufficiency or supporting policy making should therefore include these practices. Whether fish processing will become a substantial part of PUFS remains to be observed, but processing wastes are likely to be reused within urban boundaries, e.g. as fertilizers (see Section 2.3) or soil conditioner (López-Mosquera et al., 2011). Goddek et al. (2015) identified emerging challenges regarding sustainable, viable scaling up and found that fish fodder is a crucial component as it determines indirectly the quality and composition of the fertilizer and therefore the plant growth properties for different plant species. One potential way of overcoming this is to incorporate some soil into the system, which hosts earthworms and microorganisms, tailoring the nutrient availability to the plants (www.topfarmers.eu). Another study investigated the overall sustainability of different commercial aquaponic systems and reported that the largest contribution to environmental impacts (abiotic depletion, global warming potential, acidification and cumulative energy demand) comes from the structure itself (38-50\%), followed by the electricity usage (37-48\%) and the feed $(13-14 \%)$ (Forchino et al., 2017). It needs to be determined how to reduce electricity demand (e.g. using waste heat instead of electrical heater or low-carbon electricity) and utilize more benign building material, while the question of how the feed is sourced is also crucial. Like in other aquaculture, fish meal is typically used as feed, which often contributes to oceanic overfishing (Naylor et al. 1998). Looking at alternatives, Naylor et al., (2009) found that suitable feed needs a certain level of protein and omega-3 acids, which could be satisfied by plant-based proteins (e.g. seaweed or algae) and plant-based omega-3 acids (e.g. flax seeds or canola oil). Recently, non-conventional feeds, such as insects, have been suggested.

ii)

Insect rearing as fish fodder

Insect farming for protein production promises to reduce land requirements, generate less on-farm emissions and result in better feed conversion rates (1.5-2) compared to most animal farming, while the feed itself can be organic waste (FAO, 2012). This optimistic view needs to be considered carefully, as most of the studies generating these claims were carried out in laboratory or pilot scale (van Huis, 2013); commercial operations with large-scale production are still challenged by legal constraints and cost of production, with limited automation possibilities to date (Wise, 2017). Nevertheless, the prospects of insects as food and feed offer a new avenue to be explored for protein sourcing. A critical component, negative consumer perception, might not be easily changed when it comes to direct human consumption, but when insects are fed to fish in aquaponic systems this issue could be circumvented.

While early studies confirmed the general feasibility of replacing a part of the fish meal with insects (Bondari \& Sheppard, 1987; DeFoliart, 1991), important details were revealed by a more recent review (van Huis, 2013) which investigated studies attempting to feed organic waste to different types of insects and again feeding the insect larvae to fish. The authors found that insects purely fed on organic waste contain less omega- 3 acids and constitute therefore at best a small share of fish meal. However, when organic waste was mixed with fish offal from fish processing plants, feeding up to $50 \%$ of larvae in fish meal resulted in the 
same omega-3 content in fish. Regarding the large-scale rearing of insects, it seems that supplying low-value feed such as organic waste adversely affects insect yield and growth rate (Wise, 2017), an aspect that enterprises are attempting to solve. Profitable processing is another challenge, which potentially could be overcome through selling specific insect material, such as chitin, lipids, protein as high-value products and insect manure as soil conditioner for UA (NextProtein (http://nextprotein.co), Protix (https://protix.eu)).

All this indicates that larvae ideally have to be fed with some fish offal or other omega-3 rich low-value feed, or the processed larvae have to be fortified with plant-based proteins (such as seaweed) and omega-3 acids to create suitable fish meal. In both instances, the upcycling of organic waste into fish products is a promising aspect, which in turn has the potential to improve the overall sustainability of aquaponics operations. Insect rearing can also be carried out in abandoned buildings or old warehouses, thus creating, with aquaponics, upcycle potential for older buildings. First LCA studies have been carried out, e.g. for producing black soldier fly powder from organic waste, finding considerable energy inputs (drying process) but great potential for $\mathrm{N}$ fertilizer reduction (soy meal replacement for fish and remaining substrate for farming) and land use reductions (Salomone et al. 2017). Other improvement opportunities and potential synergies exist: directly feeding live larvae to fish could potentially reduce downstream processing requirements, substrate compost could be used locally in soil-based urban farming, and waste $\mathrm{CO}_{2}$ and heat could be used in greenhouses.

\subsection{Challenges and emerging opportunities for sustainability within PUFS}

After an initial optimism about guaranteed sustainability benefits of UA endeavors, recent research has generated a much more nuanced picture. This section highlights the most critical drivers, providing context for future research, urban planning, and policy making. It has to be noted that some LCA studies comparing $\mathrm{UA}$ and its conventional counterpart include the structural components when they are known for both systems, while others focus on the operational footprint (e.g. inputs, climate control, distribution) only. Most of the infrastructure of the conventional or current system is already in place, hence making comparisons based on purely operational footprints avoids accounting ambiguities to some extent. If remote food supply is compared against urban production, the impact of food miles is typically included in the assessment. In this section, an effort is made to ensure the assumed boundary of each LCA study cited is evident. Given the variation in the assumed boundaries by different LCA work, due care must be taken in any attempt to compare results between studies.

i) High-yield practices equate to high-energy, particularly in colder regions

Greenhouses with their controlled environment involve trade-offs. Stanhill (1980) compared the energy intensity per unit yield, including the structure and non-food inputs, and found that heated greenhouses in England and Germany are much more energy intensive than hoop houses and open field production in warm climates (such as Israel and California). Similar findings were obtained in a more recent, LCA-based study comparing tomato greenhouse production in Austria (1.37 kg CO$/ 2$ kg tomato) with the imported supply from unheated greenhouses in Spain and Italy, with half the related emissions $\left(0.68 \mathrm{~kg} \mathrm{CO}_{2} / \mathrm{kg}\right.$ tomato $)$ for the imported produce from warmer regions (Theurl et al., 2014). In the same study, tomatoes grown locally and organic in low-yield hoop houses only had $0.18 \mathrm{~kg} \mathrm{CO}_{2}$ per $\mathrm{kg}$ of tomato. A comparison of environmental impacts between the operations of hydroponically grown lettuce in greenhouses in Arizona and conventional open-field agriculture revealed 11 times higher yield and 12 times less water requirement by the former on one hand but 82 times greater energy requirement, with heating and cooling as the main culprits (Barbosa et al., 2015).

Taking into account the contributions of distribution and urban symbiosis, Goldstein et al. (2016a) performed a full LCA of existing UA projects fitting into the four main categories, i.e. a combination of (i) building integrated or ground-based and (ii) conditioned or non-conditioned growing environments. They 
found that for tomato and lettuce production in Boston, despite distribution losses and transport miles of the conventional supply, only the non-conditioned, ground-based, low-yield practices lead to reduced emissions. Conditioned growing environments, exhibiting high-yields per unit area, performed significantly worse than the conventional supply. The major contribution in these cases were the operational inputs (especially energy) as well as the structural requirements, in particular on rooftops with more difficult construction procedures.

A simulation workflow for optimized building-integrated agriculture compared the environmental performance of rooftop greenhouses and shipping container-based vertical farming in four cities - Lisbon, Singapore, Paris, and New York with the corresponding conventional supply (Benis et al., 2017a). The authors found that when focusing on operational energy use, the integrated rooftop greenhouses outperformed the vertical farming in shipping containers but still used between 1.01 (Paris) and 7.15 (Lisbon) times more energy than the conventional supply. Two factors played a major role: 1 ) the climatic conditions, with milder climates resulting in less energy use and 2) the current supply mix, where Paris already draws their horticultural products from energy-intensive greenhouses while Lisbon enjoys open-field supply from adjacent regions. Nevertheless, when considering operational greenhouse gas (GHG) emissions including transport and excluding the structure, the integrated rooftop greenhouse production with very high yields always outperformed the conventional supply.

These studies indicate that the relative sustainability of high-yielding conditioned UA practices is complex and their advantages over conventional systems appear to require further analysis. In particular, their comparative performance depends heavily on whether the conventional supply is already sourced sustainably, whether a great deal of energy is used for heating or cooling, and whether heat and electricity are derived from fossil-heavy grids. All these factors make the comparison very location and productionstrategy dependent.

ii) The inconvenient truth of vertical indoor farming

Highly conditioned indoor farming, using optimized lighting and other growing condition, may result in the highest obtainable yields (Touliatos et al., 2016). The industry is also booming, with multi-million dollar investments into single projects and almost twice as much revenue per growth area as greenhouse and horizontal hydroponics operations (Agrilyst, 2017). Evaluating such promising production systems, Shiina et al. (2011) conducted a life cycle analysis to evaluate resulting $\mathrm{CO}_{2}$ emission from the operation of two different types of plant factories, one using only artificial light and a hybrid one with additional utilization of sunlight. They found that the hybrid factory emitted $2.3 \mathrm{~kg} \mathrm{CO} 2$ per $\mathrm{kg}$ of spinach versus $6.4 \mathrm{~kg} \mathrm{CO}$ emitted by the total control type factory. The largest contribution in both instances was electricity used for lighting and air conditioning. To understand the effect of seasons on the associated operational emissions, conventional supply of lettuce in the UK was compared with a simulated vertical farm (Al-chalabi, 2015). Conventional produce was found to be much less energy intensive in summer $(0.33 \mathrm{~kg} \mathrm{CO} / \mathrm{kg})$ than in winter $(2.62 \mathrm{~kg} \mathrm{CO} / \mathrm{kg})$, mainly due to the supply being satisfied from greenhouses and imports. Therefore, the associated emissions of vertical farming were only twice as high in winter $\left(6.39 \mathrm{CO}_{2} / \mathrm{kg}\right)$ while five times as high in summer $\left(1.78 \mathrm{~kg} \mathrm{CO}_{2} / \mathrm{kg}\right)$. As artificial lighting is the main cause for the emissions, new technological developments in light emitting diode (LED) technology have been compared to conventional supplementary lighting in greenhouses, e.g. high pressure sodium lamps (Nelson and Bugbee, 2014). While some energy savings were found, the cost per photon delivered was 2.3 times higher for LEDs, calling for the necessary development of different lighting technologies to further reduce cost and electricity consumption. Despite new advances in climate regulation, lighting technology and automation (Agrilyst, 2017), the significant gap between the current status and the desirable future means that it will probably take many years of development and need a larger share of renewable energy in the grid in order for vertical farming to become a serious contender for reducing environmental impacts of a city's food system. 
iii) Reduced energy use and $\mathrm{CO} 2$ emissions through rooftop-building integration

Although still defined as building-integrated UA, rooftop greenhouses differ from vertical farming as they typically receive sunlight, and can be designed for natural ventilation, while still benefiting from the thermal mass and waste streams of their host building (Proksch 2016). This has great potential to reduce environmental footprints, as evaluated in several studies. The benefits of additional insulation on rooftops (through greenhouse installation) on energy consumption reduction in buildings have been evaluated by Castleton, Stovin, Beck, \& Davison (2010). They suggested significant energy savings for non-insulated buildings but very small or negligible savings for well-insulated buildings. The difference in energy requirements to heat a building with a greenhouse on the rooftop versus heating the two in isolation on the other hand is most significant for poorly insulated buildings (up to $41 \%$ ) and still considerable on wellinsulated buildings (up to 13\%), indicating the thermal mass of the roof as a decisive aspect (Delor, 2011). Historically, greenhouses were built around stone walls, acting as thermal storage of solar energy and enabling its subsequent release at night (Hall, 1989). This synergistic effect was taken into account in a simulation study for an integrated rooftop greenhouse in Barcelona and resulted in a reduction of emissions versus the conventional supply by a factor of three (Benis et al., 2017b).

Building-greenhouse synergies are not limited to heat exchange through roofs and can include the utilization of other streams such as waste heat, $\mathrm{CO}_{2}$, and collected rainwater. A theoretical study was performed on existing buildings in a retail park in various global locations which exhibit favorable properties for integration due to roof type and size, urban proximity, and availability of other waste heat and $\mathrm{CO}_{2}$ (Sanyé-Mengual et al., 2018). It was found that compared to the conventional supply, the operation of rooftop greenhouses without integration of waste streams could save between 0.35 and $0.86 \mathrm{~kg} \mathrm{CO}_{2}$ per $\mathrm{kg}$ of tomato, and greenhouses that exchange waste heat and $\mathrm{CO}_{2}$ between 0.48 and $1.3 \mathrm{~kg} \mathrm{CO}_{2}$ per $\mathrm{kg}$ of tomato. The variation in savings was mainly caused by climatic conditions, where the benefit was either reduced heating requirements in colder climates (e.g. Germany and Netherlands) or increased plant yield through higher $\mathrm{CO}_{2}$ concentrations in greenhouses in warmer climates (e.g. Spain and Columbia). The potential for these exchanged flows with buildings has been reviewed by Mohareb et al. (2017) and quantitatively confirmed by Nadal et al. (2017). The latter found significant reductions of operational emissions in a pilot project in Barcelona compared to a gas-heated, isolated greenhouse (by $82.4 \mathrm{~kg} \mathrm{CO}$ (eq) $/ \mathrm{m}^{2} /$ year). Besides the utilization of rainwater and $\mathrm{CO}_{2}, 341.93 \mathrm{kWh} / \mathrm{m}^{2} /$ year of thermal energy has been reused. A full LCA was made for the same pilot project, revealing 50-75\% reduced environmental impacts versus the current supply transported from low-tech greenhouses, with more pronounced impact reduction during summer (SanjuanDelmás et al., 2018).

The benefits of building-greenhouse integration have also been studied in comparison with alternative uses of rooftops. Evaluating the holistic socioecological benefit of rooftop agriculture as well as that of photovoltaic solar panels (PV), Benis, Reinhart, \& Ferrão (2018) compared the net present value (NPV) of these investments, including the revenues of the food or electricity, a carbon tax (10€/tonne until 2030 and $35 € /$ tonne after) based on the full LCA, and the job creation potential. Distributing directly to the consumer via farmer's markets, all types of rooftop agriculture had higher NPV than the PV system (NPV: PV < open intensive < low-tech hoop houses < building-integrated greenhouses). If produce was sold to retailers, the building-integrated greenhouses were still more than twice as economical as the PV system. Note that it is not apparent in any of these studies whether the impact of material logistics (moving materials and goods up/down from the rooftop) was considered.

The above studies indicate that integrated rooftop agriculture is a strong contender for increasing the food supply sustainability, with both season-extending hoop houses and fully integrated high-tech greenhouses as potential practices. One limitation of most of these existing evaluations lies in their theoretical nature; future research incorporating proven data, ideally sourced from trials in different regions, is required to further evaluate the benefits of such schemes. 
iv) Synergistic benefits through on-site integration with waste conversion technologies

Besides integrating greenhouses on rooftops with their host building, isolated greenhouses can also profit from energy integration by coupling them with certain waste conversion technologies. Estimating the environmental benefits of integrating a dairy-farm's anaerobic digestion vessel with a greenhouse, Zhang, Bi, \& Clift (2013) modelled the exchange of biogas energy, biogenic $\mathrm{CO}_{2}$, and digested slurry as fertilizer. Measured against the non-integrated operation, they obtained a $65-90 \%$ reduction of negative impacts over global warming potential and other LCA categories. A commercial waste management company (SUEZ, 2017) combined a waste incineration plant with a tomato greenhouse in France, using the generated heat energy to control the growing environment, achieving operational emissions reduction of around $1 \mathrm{~kg} \mathrm{CO}_{2}$ per $\mathrm{kg}$ of tomato. Similar environmental benefits have been obtained by co-locating tomato greenhouse production with a micro CHP gasification plant fueled by forest residues in Norway (Nordenström et al., 2010). Exploiting the availability of urban organic waste, a pilot project in Ohio integrated small-scale AD units in a hydroponic greenhouse, using digestate as fertilizer and the greenhouse heat to operate the mesophilic AD unit (Davis, personal communication, May 2, 2018). In their previously mentioned digeponic system, Stoknes et al. (2016) claim an operational energy demand reduction of $80 \%$ by integrating a small-scale $A D$ and combined heat and power plant (CHP) unit with a bubble-insulated greenhouse, making use of the generated $\mathrm{CO}_{2}$, electricity and waste heat. These studies display promising potential for integrated waste and food systems on a small scale, especially applicable in isolated, ground-based greenhouses. A few aspects which have not been sufficiently researched include refining the technical integration pathways, how to deal with safe equipment operation in urban environments, and evaluation of the capital expenditures, including associated emissions, of these systems.

v) Additional emission reduction potential through fertilizer and substrate substitution

Beyond the energy-efficiency measures through either building integration or housing waste conversion technologies in or close to greenhouses, additional possibilities to further improve the environmental performance of PUFS should be considered. An LCA of an integrated rooftop greenhouse (iRTG) was conducted by Sanyé-Mengual, Oliver-Solà, Montero, \& Rieradevall (2015), who found that when including the structure but excluding packaging and distribution, mineral fertilizers make up $31 \%$ and substrate $12 \%$ of the associated GHG emissions. Another study, collecting data for the same hydroponics iRTG, found that fertilizer and substrate combined made up around $40 \%$ of the emissions for summer production and around $25 \%$ of the emissions for winter production (Sanjuan-Delmás et al., 2018). These studies indicate that the option to recycle urban organic waste to produce fertilizer and growth substrate, as mentioned in section 2.4, might bring significant benefits regarding overall sustainability of soil-less growing systems. It remains to be identified how those circular systems perform in a life-cycle evaluation, including variations in collection strategy for urban organic waste.

Considering soil-based UA, researchers compared organic and conventional practices for greenhouse tomato production in Beijing (He et al., 2016). The organic system, utilizing manure and other organic fertilizers, achieved around $20 \%$ lower emissions while averaging over $50 \%$ reduced impacts over all LCA categories per unit weight. However, the yield per unit area for the organic system was around $25 \%$ lower, as expected for organic soil-based systems. Employing different types of compost instead of potting soil on rooftop growing beds in Paris and conducting an LCA, Dorr et al. (2017) found emission to be reduced by $17-47 \%$ depending on the type of crop and compost. One of the potential drawbacks from conducting soil-based agriculture in cities is nutrient-run off, which is a particular concern for heavily fertilized systems. A study looking at nitrate leaching of both intensive conventional and intensive organic garden projects found that nitrogen is lost in both cases through volatilization or leaches into the ground water (Cameira et al., 2014). The authors recommended careful and educated input dosing and plant irrigation to minimize the environmental 
burden. For soil-based UA, the aim should ideally not be to maximize productivity but to focus on providing ecosystem services and reducing disservices.

vi) Indirect influence on sustainability of certain operating and business models

Another aspect of every UA endeavor, or the creation of PUFS in general, is the effect on the residents involved in the work required as well as the consumers enjoying the harvest. Increased dietary diversity and consumption of fruits and vegetables may not only provide health benefits but also increase awareness of the seasonality of food. A survey of customers involved in different community supported agriculture (CSA) projects indicated a correlation between the length of exposure to CSA and an increased vegetable consumption and augmented preferences (Wilkins et al., 2015). The authors concluded that participating in an inclusive business model like CSA can increase the dietary diversity and quality, while allowing better alignment of seasonal produce with consumer preferences. Similar findings have been obtained for cooperatives and CSA for UA in particular (Opitz et al., 2017). Looking at the potential of (peri-) UA to mitigate the environmental impacts of food systems, it was found that a potential change in diet towards more fruits and vegetables and fewer animal products results in even greater impact reductions than shortening transportation distances and eliminating losses and wastage (Benis \& Ferrão, 2017). Further work in this area can provide relevant insight on whether participation in UA projects, either as participant or beneficiary, causes these dietary pattern changes and higher appreciation of food in general. Another factor pertaining more to community projects than to commercial ones is the preservation of genetic crop diversity, attributed to the interest of hobby gardeners to plant foreign, innovative or otherwise easily spoilt crops (Koegler et al., 2017). While it is less likely that non-accessible and private projects come with the same benefits, it remains to be identified which business models have the greatest impact on overall food system sustainability.

\section{Missing puzzle pieces}

The development of PUFS requires a great number of considerations in different areas. The urban resource integration and sustainability drivers have been discussed earlier and slowly a picture emerges for these topics in the existing literature. On the other hand, several broader considerations regarding the supply chain as well as socioeconomic impacts and development factors have not been sufficiently and systematically covered yet. These are very important for fully understanding and realizing the potential of $U A$, hence this section sheds light on existing research while highlighting related future research requirements.

\subsection{Distribution and urban logistics}

Increased food production within urban boundaries also affects urban transport systems, and the distribution and retail methods can differ from conventional supply chains. To enhance urban sustainability via PUFS, it is therefore crucial to investigate their logistics and corresponding urban environment impact. The general consensus on the significance of extra-urban transport on overall emissions of the current food system is that the contributions are typically low and do not alone justify further localization of produce (Garnett, 2011; Weber \& Matthews, 2008). However, that refers to all products of the entire food system. It may be that for fresh produce a different picture emerges - for example Plawecki et al. (2014) identified transportation as the key component implicating local (Michigan, USA) lettuce production in hoop houses as more carbon-friendly than production from the Southwestern United States.

With respect to current $U A$, it seems that some distribution models are much less efficient, up to a point where all potential environmental benefits of UA are negated. An urban farm in the United States delivers produce in small batches with a pick-up truck directly to the consumer, causing significant emissions (Goldstein et al., 2016a). In another consumer perception study, different distribution schemes were 
evaluated based on their sustainability and it was found that direct on-farm sales performed the worst due to the high use of individual vehicles for small quantities of food (Schmutz et al., 2017). Future comparisons between PUFS and the conventional system cannot stop at the retail stage but have to investigate the impact holistically up until the product reaches the place of consumption as well as any differentials in waste and food loss by consumers. Additionally, scaling up PUFS will likely require storage due to a discrepancy in supply and demand, resulting in the need to further understand space and energy requirements of storage and distribution sites.

Another consideration is upstream transportation requirements, e.g. for fertilizer and compost. Weber and Matthews (2008) showed that the general transport related emissions were around $7 \%$ of the total footprint of food in the United States, which included animal feed, natural gas transport to farms and other components which might not apply to UA. At the same time, however, providing construction material or farming inputs in congested urban environments would very likely come with a greater environmental impact than on empty rural roads. Similar studies on the implications of upstream transport on environment and traffic are yet to be carried out for urban farming.

There is likely great potential for innovative concepts in the logistics of urban farming. A potential solution to the problem of physically moving solid resources within the city without contributing to congestion or further GHG emission is the use of small electric vehicles. A community farm project in the United Kingdom reduced GHG emissions by transporting produce via bicycles from gardens to short-term storage and distribution centers, while small electric vans distribute the produce to the urban consumers (Kulak et al., 2013). Some postal companies are developing purpose-built small electrified vans that are cheaper to produce due to reduced battery and chassis requirements, which could also be used in PUFS (Ayre (2017), BBC (2017)). Furthermore, electric cargo bicycles, such as the DHL Cubicycle, could be used to distribute compost and produce, potentially contributing to emission reductions for both up- and downstream transport (DHL, 2017). Both of these novel vehicle solutions could benefit from app-based technology similar to Uber, which would optimize routes and pick-up points and match supply and demand. As stated earlier, the final impact of these types of developments would depend, in part, on the percentage of renewable energy in the grid used for charging. Further studies may wish to incorporate these novel methods to evaluate their impact.

Considering food packaging and associated emissions, there is also potential for innovation and increased resource circularity in local supply chains. As part of an LCA study comparing rooftop greenhouse production with distant low-tech greenhouse production, it was found that reusing sturdy HDPE packaging could reduce packaging emissions from 0.32 to $0.01 \mathrm{~kg} \mathrm{CO}_{2}$ per kg of tomato (Sanyé-Mengual et al., 2012). Besides reuse and recycle of packaging, UA may also reduce the need for unsustainable packaging to some extent by offering more fresh produce. Looking specifically at the emissions caused by processing and tinning of tomatoes versus those of customary PET packaging, a study found a multiple fold reduction in $\mathrm{CO}_{2}$ emission by the latter (Theurl et al., 2014). Future work should increase innovation and understanding of smart circular packaging concepts, which are made possible through the producer-consumer proximity of urban farms. Expanding PUFS, some processing and packaging will also likely occur within urban boundaries, necessitating an understanding of the requirements regarding operation and facilities.

\subsection{Economics}

Mainly praised for its potential benefits for the community and the environment, urban farming currently stands on challenging financial ground in competition with conventional rural farming, which can often make use of cheap land and governmental subsidies. If urban farming activities turn out to be inherently noneconomical, there is perhaps not much point in scaling it up. Nevertheless, a number of existing projects have reported success in finding a sustainable business model; changing regulation and subsidy structures might further facilitate financial independence for future urban farming endeavors (Agrilyst, 2017). If a city 
or council intends to scale up UA and develop PUFS, there is, however, a great need to better understand the commercial obstacles and evaluate whether financial incentives may be justified by the potentially positive impact on the local economy.

\section{i) Affordability and cost}

The cost structure for the different types of UA is very different, ranging from "free" backyard gardening to capital-intense newly built vertical farming facilities. For example, a €200 Million concept study for a 37 floor vertical farm, producing 3,500 tons of fruits and vegetables and 140 tons of tilapia fish annually resulted in non-competitive production cost of 3.50-4.00 $€$ per $\mathrm{kg}$ of tomato (Banerjee and Adenaeuer, 2014). These unfavorable economics have already lead some high-tech endeavors into bankruptcy (Beytes, 2017). While ground-based community farms are typically on public or mutually leased land and share the produce amongst the participants, rooftop farms are under more economic pressure as they compete with supermarket produce and pay utilization and access fees to the building owner. If a project is run for profit the production cost for a $\mathrm{kg}$ of produce compared to typical market prices is critical. For high-yielding practices with a higher upfront cost, such as hydroponics, the cost per unit weight depends strongly on the yield. Analyzing the price sensitivity in relation to yield, a study found proportional increase in the production cost of tomato (from $€ 0.70$ to $€ 1.50$ per $\mathrm{kg}$ ) when the yield was half the assumed value, effectively reducing the margin below the profitability threshold (Sanyé-Mengual et al., 2015). Another study evaluated the NPV of different types of rooftop agriculture and found that selling through a retailer, allowing for less margin, only enabled an integrated rooftop greenhouse with very high yield of around $70 \mathrm{~kg} / \mathrm{m}^{2}$ to make financial sense. Community supported agriculture promised here an economic avenue to reduce risk, cut out the middleman and increase ownership and support (Benis, Reinhart, and Ferrão 2018). Consumer's willingness to pay a premium can also be increased through marketing socioecological benefits, and many commercial projects draw additional funds from educational access, social employment benefits and development grants (Proksch, 2016). However, this would also probably have the impact of it not being widely available to those most in danger of food and nutrition insecurity. Despite the sensitive nature of the secrets of the industry, especially in relation to high-tech growing practices, future research can inquire, synthesize, and develop pathways to economic sustainability. Increased affordability of produce and attraction of entrepreneurial spirit would greatly facilitate the scaling up process and help unlock the socioecological benefits that PUFS promise.

ii) Impact on employment and business opportunities

Besides producing nutritious fruit and vegetables in the urban environment, the implementation of PUFS also entails employment and business opportunities. At times of digitization and advanced automation, in which the increased demand for a highly educated work force will cause a loss of skilled labor in urban areas and hence reduced opportunities for people without university degrees, new jobs around UA might be a welcome side effect (Rajnai and Kocsis, 2017). These could include (landscape) gardeners, hydroponics and automation technicians, processing and packaging laborer, delivery drivers and many more. It remains uncertain, however, whether the higher living cost in cities, and therefore the wage need, affects the potential profitability of urban farms. Another factor is the degree of automation (e.g. planting and picking) in high-yielding greenhouses, reducing the need for skilled labor. Nevertheless, considerable employment has been created by current flagship companies in the industry of high-yield UA, e.g. LufaFarms, with 140 team members for 3 rooftop greenhouses (https://montreal.lufa.com/en) - the wages and relative employment levels of these team members is unknown. Some companies also run parts of their operation as non-profits, thus attracting volunteers, or obtain tax breaks by employing individuals with disabilities as part of a corporate social mission (Proksch, 2016). Further research may look at existing projects to find out how attractive these new kinds of jobs are, whether publicly funded education programs can help build a skilled workforce, and how business models such as the low-profit limited liability (L3C) company in the US can be adopted in other countries. In addition, further work on livable wages and the wage structure generally in 
the food system relative to the cost of food would be useful and would allow for benchmarking urban food production to a better standard of living than the current food system.

Other considerations include boosting the attractiveness for (social) entrepreneurs to start up an urban farming business, how much a city's GDP can be increased as a consequence of urban farming activities and whether poorer neighborhoods can benefit from running a community business, selling to other parts of the city (Goldstein et al., 2017). These topics require broader and more nuanced inquiry, to offer solid arguments for urban decision-makers to support the development of PUFS.

\subsection{Pathways for scaling up}

The creation of effective and societally beneficial PUFS necessitates favorable legislation and regulation, a multitude of stakeholders to work together, as well as more standardized construction procedures and urban-tailored landscape building expertise.

i) Policy and institutional mechanisms

Since the foundation of advanced cities, there exist authorities that have historically enabled a certain selfsufficiency of their inhabitants (Barthel and Isendahl, 2013). This trend could be particularly observed when local authorities have more legislative scope, such as in Cagayan de Oro in the Philippines after 1991. A City Agriculture Office was created which coordinated actions, education, and organized cooperatives; the Department of Trade offered local training courses in horticulture and food processing while the local media was instrumentalized to create awareness and promote support (Potutan et al., 2002). Other institutional mechanisms have been reviewed by Pearson, Pearson, \& Pearson (2010), such as government zoning in Toronto, designating farmland with lower land tax in New South Wales, governmental land acquisition for leasing to farmers in Ottawa, and publicly provided maintenance of edible gardens in Canberra. Best practice sharing is also helpful, which includes subsidized compost schemes, linking farmers to grant programs, and providing financial benefits to new property development projects that incorporate urban farming (Doherty, 2015). Long-term assessments of urban farming activities after certain interventions can provide useful insights, such as the introduction of the Productive Green Land Act in a ward in Tokyo, which subsidized urban farming (Sioen et al., 2017). Comparing communal UA programs of different cities can also provide understanding regarding the interplay of local context and certain types of advocacy (Prové et al., 2016). Furthermore, multi-aspect support might accelerate the overcoming of obstacles, combining amendments in subsidies, the tax system, land access, and building regulation as well as new waste management strategies (MacRae et al., 2012). Current academic discourse could be enriched by further understanding the impact of various measures and their public perception, the cost-benefit ratio of financial incentives, how mechanisms can be tailored to cultural and geographical peculiarities, and the reasons why some measures have worked and others have not.

ii) Stakeholder encouragement

The establishment of PUFS requires the acceptance and contribution of many people living in a city, thus requiring broad endorsement and encouragement. Local authorities need to support its development, the current food industry and retail systems needs to incorporate it, and a multitude of participants, volunteers, entrepreneurs and investors ought to be involved, and inhabitants need to at least respect the existence of UA in their neighborhoods. For example, a lack of public approval or even active aversion can lead to vandalism, to which urban farming is especially susceptible due to its openness and fragility of the plants (Gasperi et al., 2016). In a study on public perception regarding UA, it was found that citizens were concerned about unnatural growing techniques, unclear environmental impacts and economic benefits as well as gentrification (Specht and Sanyé-Mengual, 2017). Further research could provide answers to some of these uncertainties and design effective policies to mitigate these concerns. 
More involved actors also have different motivations and thus ideas of how future PUFS should look like, as shown by McClintock \& Simpson (2017). Their study reveals that UA is a contested field, with some stakeholders tending towards individual and business-oriented solutions and others at more community and social benefits-oriented solutions. Furthermore, public acceptance seems to be higher for open access business models compared to the private and closed access ones, mostly driven by the positive perception of multipurpose UA (Specht et al., 2016a). These insights suggest that policy should aim to balance societal needs (e.g. sustainability, resilience) with resident needs (e.g. aesthetics, type of growing practice). Future work may look at how this is best achieved in practice, which stakeholders are most relevant for successful implementation and how stakeholder perception changes over the years and why. Looking at both, actively resisting and disapproving individuals as well as engaged and optimistic activists, it is important to understand their motivation, making the voices heard in a mediated environment and innovating mutually accepted pathways. One way of doing this is through participatory stakeholder workshops, which bring together a breadth of different actors, establish collaborative networks and help actors consider the perspective of others (Specht et al., 2016b). Future work can build on those experiences, refine the process and create tangible guidelines for more self-organizing forums.

\section{iii) Technical feasibility}

On top of the approval of the wider society (i.e. desirability) and a supportive legislative framework (i.e. viability), the elements of PUFS also need to be technically feasible with current technology at reasonable expense and effort. The promising integration of greenhouses on buildings, reviewed earlier in the paper, still comes with some technical uncertainties (Cerón-Palma et al., 2012). The construction on tall buildings within a dense city environment might entail significant disturbances and pose some safety risks. Utilization of waste heat and $\mathrm{CO}_{2}$ via outlets of air conditioning equipment or other sources is technically complex and very much depending on the building type. Pipes that carry fuel gas used for heating need to be connected and erected according to safety standards, especially in densely populated urban environments. Exchanging water flows with the building, e.g. greywater, might also be challenging, taking into account external building aesthetics and structural requirements and insulation. Different disciplines have to work together to deliver potential innovations and solutions to these issues and shed more light on the retrofit requirements to allow more sensible judgements on the potential of UA. An exemplary study by Angrill et al. (2012) looked at the best set-up for rainwater storage tanks and found that distributed tanks over the roof come with the least structural requirements and environmental impacts, while tanks on the floor level or underground had prohibitive energy requirements for pumping. In productivity assessments the inquirer can conduct surveys of individual buildings and identify criteria together with structural specialists as well as the facility managers and maintenance personal, as has been done in a recent study for a Barcelona district (Nadal, et al., 2017). Further work could draw from accumulated knowledge of commercial conversions and collate data and learnings needed for reliable assessment.

For ground-based projects, it is yet unclear how challenging a potential conversion of non-pervious surfaces is and whether that is desired. Furthermore, as greenhouse structure presents a considerable contribution to environmental impact (Goldstein et al. 2016), more benign materials need to be developed and produced in quantities that would ensure affordability, especially for community and hobby farms. Mass manufactured hoop houses or backyard hydroponic growing kits could facilitate smaller-scale urban farming and make it more accessible. Potential environmental concerns, such as nitrogen run-off and pollutant uptake can be limited by smart landscape design (Wortman and Lovell, 2013) but requires further quantification and tested solutions. The stability and needs of organic hydroponics systems are also not fully understood, although the technology in general has created an extensive amount of pertaining literature (Lee and Lee, 2015). Further along the value chain, processing and packaging operations most likely need to be scaled down (compared to conventional systems) while keeping capital cost proportional. 
In short, there is a great deal of work to be done to tackle the more technical aspects and academia, industry and other interest groups are best positioned to tackle them when working together.

\section{Summary and outlook: Realizing the transformative potential of PUFS}

In this review, we have analyzed the existing literature on UA with the attempt to both consolidate existing knowledge and raise important issues that require future attention. Table 2 summarizes the learning and recommendations as well as the challenges and research gaps identified. To highlight the key points, the following recommendations are made for future developments with respect to different types of available surface area for growing crops:

$\rightarrow$ Small to medium urban patches: Ground based community or CSA projects with focus on inclusiveness and ecosystem benefits, open air and unheated hoop houses

$\rightarrow$ Large plots of urban lands or suburban areas: Greenhouses with integrated waste conversion technology, constituting a decentralized network of waste assimilation points

$\rightarrow$ Rooftops: Greenhouses or unheated hoop houses with focus on building integration, rainwater catchment and high yield practices

$\rightarrow$ Aquaponics: Wherever possible, based on structural integrity and size of area depending on economics

In terms of the key challenges, we highlight the following as targets for future research:

$\rightarrow$ Deepening the technical understanding of schemes with emerging technologies, e.g. organic hydroponics based on digestate use and vermicomposting, insect rearing, and new greenhouse types

$\rightarrow$ Deepening the technical understanding of integrated schemes, e.g. integration of micro-scale AD in greenhouses, combination of digeponics and aquaponics, and utilization of building waste streams such as heat, water and $\mathrm{CO}_{2}$

$\rightarrow$ Detailed life-cycle assessment of environmental and resource impacts of emerging and integrated schemes as well as the landscape/climatological variations across the globe

$\rightarrow$ Investigation of key environmental and food safety issues arising from circular UA, such as run-off and microplastics

$\rightarrow$ Development of decentralized logistic schemes for reduced emissions and reduced traffic disturbance

$\rightarrow$ Assessment of the impact of financial and other policy measures on the development of UA

$\rightarrow$ Understanding the impact of different business models on the environment as well as stakeholder groups of UA with different interests

Given the pressure on the current food system, the increasing interest from citizens and businesses as well as the numerous positive examples, UA is likely to continue developing. However, the direction and nature of its development are still uncertain. Considering the extremes, it could either be an exclusive, profit-driven, private activity or a multipurpose, fully accessible community-based activity. We have made an implicit proposition that there is a comprehensive economic, environmental and social role for UA or PUFS to play in improving food system sustainability and human food security. In the literature, there are many contradictions about the socio-ecological promises of UA (McClintock, 2014) and stakeholder motivation is very heterogeneous (Colasanti, Hamm, \& Litjens, 2012). In our view, how PUFS should look in the future is a crucial question, one that ought to be contemplated before massive investments and policy changes are made. One particular aspect of this contemplation is a comparison with the conventional food system, which has been created, to a large extent, on the basis of exploiting natural resources, externalizing environmental impacts, maximizing profits, and ignoring problems that are not of economic urgency. The future development of PUFS, in contrast, might not be purely or primarily driven by commercial interests, but rather follow a different path to fulfill its transformative potential to urban society through multiple 
economic, environmental and social benefits. With such a premise, cautions are warranted with regard to future directions and options. For example, a hasty and non-inclusive development based on private interest might increase social injustice and gentrification and exacerbate environmental problems (Specht and Sanyé-Mengual, 2017; Tornaghi, 2014). In particular, taking into account the crucial role and promises of controlled environment agriculture (CEA) and high-tech solutions, it is important to differentiate between natural and sustainable (A. Muller et al., 2017), with the latter being desirable even when the direct growing operations are not accessible by the public. The challenge lies in designing the way these businesses are operated to increase societal gain.

To fully realize the transformative potential of UA, we propose the following overarching guiding principles, based on the research that has been conducted on this topic so far:

- A humble, considerate and environmental symbiosis-lead approach to developing PUFS helps to achieve enhanced and long-term sustainability: Respect for place and natural processes, maximizing circularity and resource-efficiency as well as minimization of environmental impacts are desirable traits for technical options.

- A participatory approach to urban farming and a co-designed PUFS should lead to a higher state of food security for all socio-economic classes and more pronounced effects regarding dietary diversity and appreciation of food.

As a final note, this review excluded some areas that pertain to UA in general. The development of PUFS in the developing world, with its peculiarities regarding population density, climate, stable electricity supply, and available funds is of paramount concern to alleviate nutritional poverty around the globe. The integration of urban farming activities with the wider food system, especially the peri-urban producers (e.g. dairy farms), can be included in resource circularity considerations with existing processing and packaging facilities utilized for multiple purposes. Embedding a potentially larger supply of food within urban areas into the existing food system with mutual benefits for all stakeholders is to be explored as well. Further areas of interest include biodiversity enhancement, utilization of black and grey water, the design of PUFS in completely newly built cities like those being established in the urbanization in China and the required courses and education for urban farmers to be offered in public institutions. It is our hope that an appreciation of existing knowledge and future challenges of these topics, together with those covered by this review, will form a solid basis to support the future healthy development of UA and productive urban food systems, eventually allowing them to realize their full societal potential.

Table 2a: Summary - Technical perspectives for growing and operations

\begin{tabular}{l|l} 
Learnings and recommendations & Challenges and research gaps \\
\hline - $\quad \begin{array}{l}\text { Growing techniques, operational modes and } \\
\text { business models should be specified when } \\
\text { discussing and evaluating the benefits and potential } \\
\text { drawbacks of UA }\end{array}$ & $\begin{array}{l}\text { Understanding of spatial and logistical requirements for storage } \\
\text { and processing/packaging, issues with economies of scale for } \\
\text { smaller plants }\end{array}$ \\
- $\begin{array}{l}\text { Nutrients and nutrient security should be the focus, } \\
\text { only partial self-sufficiency is required and desired }\end{array}$ & $\begin{array}{l}\text { Further understanding of digeponics, i.e. the optimal use of } \\
\text { digestate for individual plants (according to nutrient needs) and } \\
\text { growing practices as well as the operational stability and process } \\
\text { Rooftop farming and CEA practices should be }\end{array}$ \\
$\begin{array}{l}\text { included in future self-sufficiency assessments } \\
\text { Seasonal supply variance and storage requirements long time periods of organic systems with high } \\
\text { should be considered in future research } \\
\text { Aquaponics as fast-growing practice with consumer } \\
\text { appeal should be included in the spectrum of UA } \\
\text { activities }\end{array}$ & $\begin{array}{l}\text { Further understanding of using vermicompost teas in } \\
\text { hydroponics, stable production, optimum conditions and benefits } \\
\text { for plant growth }\end{array}$ \\
$\begin{array}{l}\text { Advancing insect rearing on organic waste as potential protein } \\
\text { and feed supply, understanding of operational efficiencies and } \\
\text { feasible types of waste }\end{array}$
\end{tabular}


- Yield data from ongoing commercial scale projects should be utilized and harmonized with simulations and models

- Crop-specific yield figures (besides tomato and lettuce) should be included in self-sufficiency assessments

- Utilization of digestates in hydroponics and substrate-based UA has proven to be feasible, requiring microbial conversion or liquid-solid separation and composting or filtering

- Innovative transport and distribution models for produce exist and traditional logistics firms may inspire bespoke development for prevention of additional burden on urban traffic
- Development and further understanding of combining digeponics (use of digestate, earthworms and microbial communities) and aquaponics

- Further understanding of feasibility of rooftop greenhouses and retrofits, "in-house" logistics, piping systems (especially for gas), drawing from accumulated knowledge of commercial conversions

- Further understanding of technical feasibility of integrating rooftop greenhouses for utilization of waste heat, $\mathrm{CO}_{2}$ and grey water

- Refining the technical integration pathways and options of greenhouses combined with micro-scale $A D$, understand how to deal with safe equipment operation in urban environments

Table 2b: Summary - Environmental and resource sustainability

\section{Learnings and recommendations}

- Sustainability depends on the way UA is set up, it has both, the potential to increase emissions if done with an "productivity above all" approach but also the potential to greatly reduce emissions when resource flows are most efficiently utilized through systematic and innovative design

- The sustainability of CEA produce in comparison to the conventional produce is strongly affected by the high energy needs in winter in Northern regions as well as the resource intensity of the current supply chain

- High-tech greenhouses have a better environmental performance when integrated with a host building, either just using the thermal mass or utilizing waste streams

- Ground-based high-tech greenhouses can be integrated with waste conversion technology (e.g. AD) for increased resource efficiency

- Open air, soil-based UA should ideally aim to focus on providing ecosystem services and reducing disservices rather than maximizing productivity

- Input (substrate, fertilizer) replacement by organic waste products should be considered, as source separation and further treatment is a growing and successful practice with promising effect on overall sustainability

- Individual transport and food delivery come with a high footprint; electrified modes of transport and distribution should be employed

- Further comparisons between PUFS and the conventional system should not stop at the retail stage but have to investigate the impact holistically up until the product reaches the place of consumption as well as any differentials in waste and food loss by consumers

\section{Challenges and research gaps}

- LCA studies on rooftop greenhouses which operate commercially

- LCA studies on the integration of greenhouses with micro-scale $A D$, including evaluation of the capital expenditures depending on size

- LCA studies for emerging technical schemes, including digeponic systems / fully circular hydroponics systems, urban insect rearing and processing to fish feed

- Development of more environmentally benign greenhouse materials

- LCA / LCO studies on upstream transport to urban farms as well as comparison with more decentralized/circular approaches and electrified forms of transport

- Development and understanding of smart circular packaging concepts, made possible through the producer-consumer proximity of urban farms

- Investigation into effects and reduction of run-off and pollutant uptake through smart garden design

- Evaluation of the effects of certain business models or UA activities on dietary diversity, reduced household food waste (through higher appreciation of food)

- Investigation into microplastics in food waste and the consequences for urban organic waste treatment

- Investigations into role of electricity grid mix in future LCA analysis

Table 2c: Summary - Interaction with society, policy and economy 
- Inclusive and multipurpose development and scaling-up can reduce negative public perception, ensure wide participation and increase the effect on dietary patterns and food-related behaviors

- Increased legislative power and authority for cities can expedite the implementation of PUFS

- Examples of different positive pathways and case studies of legislative measures exist and can be shared with policy makers in best practice workshops

- Establishment of collaborative networks and workshops with diverse actors of the (old) food system and entrepreneurial and activist citizens can help with scaling up and balancing interests

- High-tech CEA tends to be less participatory and more profit-based, hence the operating system should be designed in socioecologically beneficial ways
- Assessment of past, existing and potential taxation and financial incentive regimes on i) their contribution to increased UA activity, ii) their effect on the socio-ecological considerations of project owners and farm operators and iii) the cost-benefit ratio of financial incentives

- Understanding of scaling-up mechanisms (besides direct financial incentives) i) how they can be tailored to cultural and geographical peculiarities, ii) post-mortem analysis of reasons why some measures have worked and others have not iii) how they are perceived in public and how policy has changed perception over time

- Understanding the effect of higher urban wages on profitability and choice of business model as well as comparison with current (lowwage) food supply and its effect on society

- Evaluation of effect on city's GDP and benefits for poorer neighborhoods (e.g. through community business or intracity sales)

- Finding the balance in multipurpose approaches (optimization) as well as between societal needs (sustainability, resilience) and resident needs (e.g. aesthetics, access)

- Community-based approaches vs. Industrial-type development approaches

- Understanding the inter-play between food-sovereignty, food security, and production strategies 


\section{Acknowledgements}

Financial support for TW for the duration of his PhD by the Clarendon Fund is greatly appreciated.

\section{References}

Agrilyst, 2017. State of Indoor Farming.

Al-chalabi, M., 2015. Vertical Farming- Skyscraper Sustainability. Sustain. Cities Soc. 18, 74-77. https://doi.org/http://dx.doi.org/10.1016/j.scs.2015.06.003

Alvarenga, P., Mourinha, C., Farto, M., Santos, T., Palma, P., Sengo, J., Morais, M.C., Cunha-Queda, C., 2015. Sewage sludge, compost and other representative organic wastes as agricultural soil amendments: Benefits versus limiting factors. Waste Manag. 40, 44-52. https://doi.org/http://dx.doi.org/10.1016/j.wasman.2015.01.027

Angrill, S., Farreny, R., Gasol, C.M., Gabarrell, X., Viñolas, B., Josa, A., Rieradevall, J., 2012. Environmental analysis of rainwater harvesting infrastructures in diffuse and compact urban models of Mediterranean climate. Int. J. Life Cycle Assess. 17, 25-42. https://doi.org/10.1007/s11367-011-0330-6

Ayre, J., 2017. Deutsche Post DHL Building 2nd StreetScooter Electric Van Factory, Doubling Production Volume | CleanTechnica [WWW Document]. CleanTechnica. URL https://cleantechnica.com/2017/10/03/deutsche-post-dhl-building-2nd-streetscooter-electric-vanfactory-doubling-production-volume/ (accessed 8.17.18).

Badami, M.G., Ramankutty, N., 2015. Urban agriculture and food security: A critique based on an assessment of urban land constraints. Glob. Food Sec. 4, 8-15. https://doi.org/10.1016/j.gfs.2014.10.003

Baltzell, A.H., 2011. The Suitability of Worm Castings \& Compost Tea in Organic Hydroponic Lettuce Propagation.

Banerjee, C., Adenaeuer, L., 2014. Up, Up and Away! The Economics of Vertical Farming. J. Agric. Stud. 2, 40. https://doi.org/10.5296/jas.v2i1.4526

Barbosa, G.L., Almeida Gadelha, F.D., Kublik, N., Proctor, A., Reichelm, L., Weissinger, E., Wohlleb, G.M., Halden, R.U., 2015. Comparison of land, water, and energy requirements of lettuce grown using hydroponic vs. Conventional agricultural methods. Int. J. Environ. Res. Public Health 12, 6879-6891. https://doi.org/10.3390/ijerph120606879

Barthel, S., Isendahl, C., 2013. Urban gardens, Agriculture, And water management: Sources of resilience for long-term food security in cities. Ecol. Econ. 86, 224-234. https://doi.org/10.1016/j.ecolecon.2012.06.018

BBC, 2017. Royal Mail's new electric vans unveiled - BBC News [WWW Document]. URL https://www.bbc.co.uk/news/technology-41025771 (accessed 8.17.18).

Benis, K., Ferrão, P., 2017. Potential mitigation of the environmental impacts of food systems through urban and peri-urban agriculture (UPA) - a life cycle assessment approach. J. Clean. Prod. 140, 784-795. https://doi.org/10.1016/j.jclepro.2016.05.176

Benis, K., Reinhart, C., Ferrão, P., 2017a. Building-Integrated Agriculture (BIA) In Urban Contexts : Testing A Simulation-Based Decision Support Workflow, in: 15th IBPSA Conference San.

Benis, K., Reinhart, C., Ferrão, P., 2017b. Development of a simulation-based decision support workflow for the implementation of Building-Integrated Agriculture (BIA) in urban contexts. J. Clean. Prod. 147, 589602. https://doi.org/10.1016/j.jclepro.2017.01.130

Benis, K., Reinhart, C.F., Ferrão, P., 2018. Putting Rooftops to Use - a Cost-Benefit Analysis of Food Production vs. Energy Generation under Mediterranean Climates. Cities 0-1. https://doi.org/10.1016/j.cities.2018.02.011 
Bondari, K., Sheppard, D.C., 1987. Soldier fly, Hermetia illucens L., larvae as feed for channel catfish, Ictalurus punctatus (Rafinesque), and blue tilapia, Oreochromis aureus (Steindachner). Aquac. Res. 18, 209-220. https://doi.org/10.1111/j.1365-2109.1987.tb00141.x

Buehler, D., Junge, R., 2016. Global trends and current status of commercial urban rooftop farming. Sustain. 8, 1-16. https://doi.org/10.3390/su8111108

Cameira, M.R., Tedesco, S., Leitão, T.E., 2014. Water and nitrogen budgets under different production systems in Lisbon urban farming. Biosyst. Eng. 125, 65-79. https://doi.org/10.1016/j.biosystemseng.2014.06.020

Castleton, H.F., Stovin, V., Beck, S.B.M., Davison, J.B., 2010. Green roofs; Building energy savings and the potential for retrofit. Energy Build. 42, 1582-1591. https://doi.org/10.1016/j.enbuild.2010.05.004

Cerón-Palma, I., Sanyé-Mengual, E., Oliver-Solà, J., Montero, J.I., Rieradevall, J., 2012. Barriers and Opportunities Regarding the Implementation of Rooftop Eco.Greenhouses (RTEG) in Mediterranean Cities of Europe. J. Urban Technol. 19, 87-103. https://doi.org/10.1080/10630732.2012.717685

Chinta, Y.D., Kano, K., Widiastuti, A., Fukahori, M., Kawasaki, S., Eguchi, Y., Misu, H., Odani, H., Zhou, S., Narisawa, K., Fujiwara, K., Shinohara, M., Sato, T., 2014. Effect of corn steep liquor on lettuce root rot (Fusarium oxysporum f.sp. lactucae) in hydroponic cultures. J. Sci. Food Agric. 94, 2317-2323. https://doi.org/10.1002/jsfa.6561

Chris Beytes, 2017. FarmedHere Shuts Down [WWW Document]. URL https://www.growertalks.com/Article/?articleid=22890 (accessed 8.15.18).

Clinton, N., Stuhlmacher, M., Miles, A., Uludere Aragon, N., Wagner, M., Georgescu, M., Herwig, C., Gong, P., 2018. A Global Geospatial Ecosystem Services Estimate of Urban Agriculture. Earth's Futur. https://doi.org/10.1002/2017EF000536

Colasanti, K., Hamm, M.W., 2010. Assessing the local food supply capacity of Detroit, Michigan. J. Agric. Food Syst. Community Dev. 1, 41-58. https://doi.org/10.5304/jafscd.2010.012.002

Colasanti, K.J.A., Hamm, M.W., Litjens, C.M., 2012. The City as an "Agricultural Powerhouse"? Perspectives on Expanding Urban Agriculture from Detroit, Michigan. Urban Geogr. 33, 348-369. https://doi.org/10.2747/0272-3638.33.3.348

Community by Design (2018), Personal Communication with Rokiah Yaman, Community by Design, in person, June 7th 2018.

Davis, S. (2018). Ohio University, Personal communication, by telephone, 02.05.2018

DeFoliart, G.R., 1991. Insect fatty acids: similar to those of poultry and fish in their degree of unsaturation, but higher in the polyunsaturates. Food Insect Newsl. 4, 1-8.

Delor, M., 2011. Current state of Building-Integrated Agriculture, its energy benefits and comparison with green roofs - Summary 0-15.

Devlin, S., 2016. Agricultural Labour in the UK: Briefing Paper. Food Res. Collab. 1-30.

DHL, 2017. DHL | Press Release | English [WWW Document]. URL http://www.dhl.com/en/press/releases/releases_2017/all/express/dhl_expands_green_urban_deliver y_with_city_hub_for_cargo_bicycles.html (accessed 8.17.18).

Dimambro, M.E., 2015. Novel uses for digestate : Protected horticulture, in: 20th European Biosolids \& Organic Resources Conference \& Exhibition. Manchester.

Doherty, K., 2015. Urban agriculture and ecosystem services:a typology and toolkit for planners Paper 269.

Dorr, E., Sanyé-Mengual, E., Gabrielle, B., Grard, B.J.P., Aubry, C., 2017. Proper selection of substrates and crops enhances the sustainability of Paris rooftop garden. Agron. Sustain. Dev. 37. https://doi.org/10.1007/s13593-017-0459-1

Duchemin, E., Wegmuller, F., Legault, a.-M., 2008. Urban agriculture: multi-dimensional tools for social development in poor neighbourhoods. F. Actions Sci. Reports 1, 42-52. https://doi.org/10.5194/facts2-1-2009

Edwards, C.A., Arancon, N.Q., Sherman, R.L., 2010. Vermiculture technology: earthworms, organic wastes, and environmental management. CRC press.

Egle, L., Rechberger, H., Krampe, J., Zessner, M., 2016. Phosphorus recovery from municipal wastewater: An integrated comparative technological, environmental and economic assessment of $\mathrm{P}$ recovery 
technologies. Sci. Total Environ. 571, 522-542. https://doi.org/10.1016/j.scitotenv.2016.07.019

Ellis, F., Sumberg, J., 1998. Food production, urban areas and policy responses. World Dev. 26, 213-225. https://doi.org/10.1016/S0305-750X(97)10042-0

FAO, 2016. FAOSTAT [WWW Document]. FAOSTAT Stat. database. URL http://www.fao.org/faostat/en/\#home (accessed 8.17.18).

FAO, 2012. The contribution of insects to food security, livelihoods and the environment 1-4. https://doi.org/i3264e/1/04.13

Forchino, A.A., Lourguioui, H., Brigolin, D., Pastres, R., 2017. Aquaponics and sustainability: The comparison of two different aquaponic techniques using the Life Cycle Assessment (LCA). Aquac. Eng. 77, 80-88. https://doi.org/10.1016/j.aquaeng.2017.03.002

Fujiwara, K., Aoyama, C., Takano, M., Shinohara, M., 2012. Suppression of Ralstonia solanacearum bacterial wilt disease by an organic hydroponic system. J. Gen. Plant Pathol. 78, 217-220. https://doi.org/10.1007/s10327-012-0371-0

Fujiwara, K., lida, Y., Iwai, T., Aoyama, C., Inukai, R., Ando, A., Ogawa, J., Ohnishi, J., Terami, F., Takano, M., Shinohara, M., 2013. The rhizosphere microbial community in a multiple parallel mineralization system suppresses the pathogenic fungus Fusarium oxysporum. Microbiologyopen 2, 997-1009. https://doi.org/10.1002/mbo3.140

Garfí, M., Gelman, P., Comas, J., Carrasco, W., Ferrer, I., 2011. Agricultural reuse of the digestate from lowcost tubular digesters in rural Andean communities. Waste Manag. 31, 2584-2589. https://doi.org/10.1016/j.wasman.2011.08.007

Garnett, T., 2011. Where are the best opportunities for reducing greenhouse gas emissions in the food system (including the food chain)? A comment. Food Policy 36, 23-32. https://doi.org/10.1016/j.foodpol.2012.04.006

Gasperi, D., Pennisi, G., Rizzati, N., Magrefi, F., Bazzocchi, G., Mezzacapo, U., Stefani, M.C., Sanyé-Mengual, E., Orsini, F., Gianquinto, G., 2016. Towards regenerated and productive vacant areas through urban horticulture: Lessons from Bologna, Italy. Sustain. 8. https://doi.org/10.3390/su8121347

Gilmour, D., Blackwood, D., Comber, S., Thornell, A., 2008. Identifying human waste contribution of phosphorus loads to domestic wastewater. Preceedings 11th Int. Conf. Urban Drainage, Held Edinburgh, Scoltand, UK, 1-10.

Goddek, S., Delaide, B., Mankasingh, U., Ragnarsdottir, K.V., Jijakli, H., Thorarinsdottir, R., 2015. Challenges of sustainable and commercial aquaponics. Sustain. 7, 4199-4224. https://doi.org/10.3390/su7044199

Goldstein, B., Hauschild, M., Fernandez, J., Birkved, M., 2016a. Testing the environmental performance of urban agriculture as a food supply in northern climates. J. Clean. Prod. 135, 984-994. https://doi.org/10.1016/j.jclepro.2016.07.004

Goldstein, B., Hauschild, M., Fernández, J., Birkved, M., 2016b. Urban versus conventional agriculture, taxonomy of resource profiles: a review. Agron. Sustain. Dev. 36, 1-19. https://doi.org/10.1007/s13593-015-0348-4

Goldstein, B.P., Hauschild, M.Z., Fernández, J.E., Birkved, M., 2017. Contributions of Local Farming to Urban Sustainability in the Northeast United States. Environ. Sci. Technol. 51, 7340-7349. https://doi.org/10.1021/acs.est.7b01011

Grard, B.J.-P., Bel, N., Marchal, N., Madre, F., Castell, J.-F., Cambier, P., Houot, S., Manouchehri, N., Besancon, S., Michel, J.-C., Chenu, C., Frascaria-Lacoste, N., Aubry, C., 2015. Recycling urban waste as possible use for rooftop vegetable garden. Futur. Food J. Food, Agric. Soc. 3, 21-34.

Hall, E., 1989. The Garden History Society Hot Walls : An Investigation of Their Construction in Some Northern Kitchen Gardens. Gard. Hist. 17, 95-107.

Hamilton, A.J., Burry, K., Mok, H.F., Barker, S.F., Grove, J.R., Williamson, V.G., 2014. Give peas a chance? Urban agriculture in developing countries. A review. Agron. Sustain. Dev. 34, 45-73. https://doi.org/10.1007/s13593-013-0155-8

Hamm, M.W., Frison, E., Tirado von der Pahlen, M.C., 2018. Human health, diets and nutrition: missing links in eco-agri-food systems.

He, X., Qiao, Y., Liu, Y., Dendler, L., Yin, C., Martin, F., 2016. Environmental impact assessment of organic and 
conventional tomato production in urban greenhouses of Beijing city, China. J. Clean. Prod. 134, 251258. https://doi.org/10.1016/j.jclepro.2015.12.004

Hernandez, O.L., Calderín, A., Huelva, R., Martínez-Balmori, D., Guridi, F., Aguiar, N.O., Olivares, F.L.,

Canellas, L.P., 2014. Humic substances from vermicompost enhance urban lettuce production. Agron.

Sustain. Dev. 35, 225-232. https://doi.org/10.1007/s13593-014-0221-x

Hertel, S., Navarro, P., Deegener, S., Körner, I., 2015. Biogas and nutrients from blackwater, lawn cuttings and grease trap residues???experiments for Hamburg???s Jenfelder Au district. Energy. Sustain. Soc. 5. https://doi.org/10.1186/s13705-015-0057-5

Hortifeeds International (2018). Personal communication with Mr P. Canales-Prati, Hortifeeds, by telephone, 26.04.2018, see also: http://www.hortifeeds.co.uk/index.php/hortikelp/

Jaramillo, F., Destouni, G., 2015. planetary boundaries: Guiding human development on a changing planet. Science (80-. ). 348, 1217-c. https://doi.org/10.1126/science.aaa9629

Junge, R., König, B., Villarroel, M., Komives, T., Jijakli, M.H., 2017. Strategic points in aquaponics. Water (Switzerland) 9, 1-9. https://doi.org/10.3390/w9030182

Kawamura-Aoyama, C., Fujiwara, K., Shinohara, M., Takano, M., 2014. Study on the hydroponic culture of lettuce with microbially degraded solid food waste as a nitrate source. Japan Agric. Res. Q. 48, 71-76. https://doi.org/10.6090/jarq.48.71

Kinney, C.A., Furlong, E.T., Zaugg, S.D., Burkhardt, M.R., Werner, S.L., Cahill, J.D., Jorgensen, G.R., 2006. Survey of organic wastewater contaminants in biosolids destined for land application. Environ. Sci. Technol. 40, 7207-7215. https://doi.org/10.1021/es0603406

Koegler, M., Jean-Paul, G.B., Aubry, C., 2017. Climate Innovation Potentials of Urban Agriculture ( CIPUrA ) Geographic Pathfinder 63.

Krikser, T., Piorr, A., Berges, R., Opitz, I., 2016. Urban Agriculture Oriented towards Self-Supply, Social and Commercial Purpose: A Typology. Land 5, 28. https://doi.org/10.3390/land5030028

Kulak, M., Graves, A., Chatterton, J., 2013. Reducing greenhouse gas emissions with urban agriculture: A Life Cycle Assessment perspective. Landsc. Urban Plan. 111, 68-78. https://doi.org/10.1016/j.landurbplan.2012.11.007

Lee, S., Lee, J., 2015. Beneficial bacteria and fungi in hydroponic systems: Types and characteristics of hydroponic food production methods. Sci. Hortic. (Amsterdam). 195, 206-215. https://doi.org/10.1016/j.scienta.2015.09.011

Lenka, S., Lenka, N.K., Sejian, V., Mohanty, M., 2015. Contribution of Agriculture Sector to Climate Change, in: Sejian, V., Gaughan, J., Baumgard, L., Prasad, C. (Eds.), Climate Change Impact on Livestock: Adaptation and Mitigation. Springer India, New Delhi, pp. 37-48. https://doi.org/10.1007/978-81-3222265-1_3

Liedl, B.E., Cummins, M., Young, A., Williams, M.L., Chatfield, J.M., 2004. Hydroponic lettuce production using liquid effluent from poultry waste bioremediation as a nutrient source. Acta Hortic. 659, 721728. https://doi.org/10.17660/ActaHortic.2004.659.93

Lin, B.B., Philpott, S.M., Jha, S., 2015. The future of urban agriculture and biodiversity-ecosystem services: Challenges and next steps. Basic Appl. Ecol. 16, 189-201. https://doi.org/10.1016/j.baae.2015.01.005

López-Mosquera, M.E., Fernández-Lema, E., Villares, R., Corral, R., Alonso, B., Blanco, C., 2011. Composting fish waste and seaweed to produce a fertilizer for use in organic agriculture. Procedia Environ. Sci. 9, 113-117. https://doi.org/10.1016/j.proenv.2011.11.018

Love, D.C., Fry, J.P., Li, X., Hill, E.S., Genello, L., Semmens, K., Thompson, R.E., 2015. Commercial aquaponics production and profitability: Findings from an international survey. Aquaculture 435, 67-74. https://doi.org/10.1016/j.aquaculture.2014.09.023

MacRae, R., Nasr, J., Kuhns, J., Baker, L., Christianson, R., Danyluk, M., Snider, a., Gallant, E., Kaill-Vinish, P., Michalak, M., Oswald, J., Patel, S., Wekerle, G., 2012. Could Toronto provide 10\% of its fresh vegetable requirements from within its own boundaries? Part II, Policy supports and program design. J. Agric.

Food Syst. Community Dev. 2, 147-169. https://doi.org/http://dx.doi.org/10.5304/jafscd.2012.022.002

Martellozzo, F., Landry, J.S., Plouffe, D., Seufert, V., Rowhani, P., Ramankutty, N., 2014. Urban agriculture: A global analysis of the space constraint to meet urban vegetable demand. Environ. Res. Lett. 9. 
https://doi.org/10.1088/1748-9326/9/6/064025

Martin, G., Clift, R., Christie, I., Druckman, A., 2014. The Sustainability Contributions of Urban Agriculture : Exploring a community garden and a community farm. Proc. 9th Int. Conf. Life Cycle Assess. Agri-Food Sect. 752-760.

McClintock, N., 2014. Radical, reformist, and garden-variety neoliberal: coming to terms with urban agriculture's contradictions. Local Environ. 19, 147-171. https://doi.org/10.1080/13549839.2012.752797

McClintock, N., Simpson, M., 2017. Stacking functions: identifying motivational frames guiding urban agriculture organizations and businesses in the United States and Canada. Agric. Human Values 0, 1-21. https://doi.org/10.1007/s10460-017-9784-x

Mohareb, E., Heller, M., Novak, P., Goldstein, B., Fonoll, X., Raskin, L., 2017. Considerations for reducing food system energy demand while scaling up urban agriculture. Environ. Res. Lett. 12. https://doi.org/10.1088/1748-9326/aa889b

Mok, H.F., Williamson, V.G., Grove, J.R., Burry, K., Barker, S.F., Hamilton, A.J., 2014. Strawberry fields forever? Urban agriculture in developed countries: A review. Agron. Sustain. Dev. 34, 21-43. https://doi.org/10.1007/s13593-013-0156-7

Mougeot, L.J.A., 2000. Urban Agriculture: Definition, Presence, Potentials and Risks, and Policy Challenges.

Muller, A., Ferré, M., Engel, S., Gattinger, A., Holzkämper, A., Huber, R., Müller, M., Six, J., 2017. Can soil-less crop production be a sustainable option for soil conservation and future agriculture? Land use policy 69, 102-105. https://doi.org/10.1016/j.landusepol.2017.09.014

Muller, A., Schader, C., El-Hage Scialabba, N., Brüggemann, J., Isensee, A., Erb, K.H., Smith, P., Klocke, P., Leiber, F., Stolze, M., Niggli, U., 2017. Strategies for feeding the world more sustainably with organic agriculture. Nat. Commun. 8, 1-13. https://doi.org/10.1038/s41467-017-01410-w

Nadal, A., Alamús, R., Pipia, L., Ruiz, A., Corbera, J., Cuerva, E., Rieradevall, J., Josa, A., 2017a. Urban planning and agriculture. Methodology for assessing rooftop greenhouse potential of non-residential areas using airborne sensors. Sci. Total Environ. 601-602, 493-507.

https://doi.org/10.1016/j.scitotenv.2017.03.214

Nadal, A., Llorach-Massana, P., Cuerva, E., López-Capel, E., Montero, J.I., Josa, A., Rieradevall, J., Royapoor, M., 2017b. Building-integrated rooftop greenhouses: An energy and environmental assessment in the mediterranean context. Appl. Energy 187, 338-351. https://doi.org/10.1016/j.apenergy.2016.11.051

NARO (National Agriculture Research Organization) (2018). Personal communication with Mr M. Shinohara, NARO, by E-mail, 07.02.2018

Naylor, R.L., Hardy, R.W., Bureau, D.P., Chiu, A., Elliott, M., Farrell, A.P., Forster, I., Gatlin, D.M., Goldburg, R.J., Hua, K., Nichols, P.D., 2009. Feeding aquaculture in an era of finite resources. Proc. Natl. Acad. Sci. 106, 15103-15110. https://doi.org/10.1073/pnas.0905235106

Neal, J., Wilkie, A.C., 2014. Anaerobic Digester Effluent as Fertilizer for Hydroponically Grown Tomatoes. J. Undergr. Res. 15, 1-5.

Neilson, C., Rickards, L., 2017. The relational character of urban agriculture: competing perspectives on land, food, people, agriculture and the city. Geogr. J. 183, 295-306. https://doi.org/10.1111/geoj.12188

Nelson, J.A., Bugbee, B., 2014. Economic analysis of greenhouse lighting: Light emitting diodes vs. high intensity discharge fixtures. PLoS One 9. https://doi.org/10.1371/journal.pone.0099010

Nordenström, E., Guest, G., Fröling, M., 2010. LCA of local bio-chp fuelled greenhouses versus Mediterranean open field tomatoes for consumption in northern Scandinavia. ECO-TECH' 10, 22-24 Novemb. 2010, Kalmar, Sweden.

NRDC, 2017. San Francisco Composting from fork to farm and back.

OCC (Oxford City Council) (2018). Personal communication with Ms A. Mates, OCC, by E-mail, 03.05.2018.

Opitz, I., Specht, K., Piorr, A., Siebert, R., Zasada, I., 2017. Effects of consumer-producer interactions in alternative food networks on consumers' learning about food and agriculture. Morav. Geogr. Reports 25, 181-191. https://doi.org/10.1515/mgr-2017-0016

Orsini, F., Gasperi, D., Marchetti, L., Piovene, C., Draghetti, S., Ramazzotti, S., Bazzocchi, G., Gianquinto, G., 
2014. Exploring the production capacity of rooftop gardens (RTGs) in urban agriculture: the potential impact on food and nutrition security, biodiversity and other ecosystem services in the city of Bologna. Food Secur. 6, 781-792. https://doi.org/10.1007/s12571-014-0389-6

Orsini, F., Kahane, R., Nono-Womdim, R., Gianquinto, G., 2013. Urban agriculture in the developing world: A review. Agron. Sustain. Dev. 33, 695-720. https://doi.org/10.1007/s13593-013-0143-z

Pearson, L.J., Pearson, L., Pearson, C.J., 2010. Sustainable urban agriculture: Stocktake and opportunities. Int. J. Agric. Sustain. 8, 7-19. https://doi.org/10.3763/ijas.2009.0468

Plawecki, R., Pirog, R., Montri, A., Hamm, M.W., 2014. Comparative carbon footprint assessment of winter lettuce production in two climatic zones for Midwestern market. Renew. Agric. Food Syst. 29, 310-318. https://doi.org/10.1017/S1742170513000161

Potutan, G.E., Schnitzler, W.H., Arnado, J.M., Janubas, L.G., Holmer, R.J., 2002. Urban Agriculture in Cagayan de Oro: a favourable response of city government and NGOs. City Case Study 413-428.

Proksch, G., 2011. Urban Rooftops as Productive Resources Rooftop Farming versus Conventional Green Roofs. Considering Res. Reflecting upon Curr. themes Archit. Res. ARCC. 497-509.

Proksch, G. (2017) Creating Urban Agricultural Systems: An Integrated Approach to Design, Routletge, Taylor \& Francis Group New York.

Prové, C., Dessein, J., Krom, M. de, 2016. Taking context into account in urban agriculture governance: Case studies of Warsaw (Poland) and Ghent (Belgium). Land use policy 56, 16-26. https://doi.org/10.1016/j.landusepol.2016.04.025

Rajnai, Z., Kocsis, I., 2017. Labor market risks of industry 4.0, digitization, robots and Al. SISY 2017 - IEEE 15th Int. Symp. Intell. Syst. Informatics, Proc. 343-346. https://doi.org/10.1109/SISY.2017.8080580

Rayns, F., 2015. Literature review : Digestate use in protected horticulture.

Russo, A., Escobedo, F.J., Cirella, G.T., Zerbe, S., 2017. Edible green infrastructure: An approach and review of provisioning ecosystem services and disservices in urban environments. Agric. Ecosyst. Environ. 242, 53-66. https://doi.org/10.1016/j.agee.2017.03.026

Saha, M., Eckelman, M.J., 2017. Growing fresh fruits and vegetables in an urban landscape: A geospatial assessment of ground level and rooftop urban agriculture potential in Boston, USA. Landsc. Urban Plan. 165, 130-141. https://doi.org/10.1016/j.landurbplan.2017.04.015

Sanjuan-Delmás, D., Llorach-Massana, P., Nadal, A., Ercilla-Montserrat, M., Muñoz, P., Montero, J.I., Josa, A., Gabarrell, X., Rieradevall, J., 2018. Environmental assessment of an integrated rooftop greenhouse for food production in cities. J. Clean. Prod. 177, 326-337. https://doi.org/10.1016/j.jclepro.2017.12.147

Sanyé-Mengual, E., Cerón-Palma, I., Oliver-Solá, J., Montero, J.I., Rieradevall, J., 2012. Environmental analysis of the logistics of agricultural products from roof top greenhouses in mediterranean urban areas. J. Sci. Food Agric. 93, 100-109. https://doi.org/10.1002/jsfa.5736

Sanyé-Mengual, E., Martinez-Blanco, J., Finkbeiner, M., Cerdà, M., Camargo, M., Ometto, A.R., Velásquez, L.S., Villada, G., Niza, S., Pina, A., Ferreira, G., Oliver-Solà, J., Montero, J.I., Rieradevall, J., 2018. Urban horticulture in retail parks: Environmental assessment of the potential implementation of rooftop greenhouses in European and South American cities. J. Clean. Prod. 172, 3081-3091. https://doi.org/10.1016/j.jclepro.2017.11.103

Sanyé-Mengual, E., Oliver-Solà, J., Montero, J.I., Rieradevall, J., 2015. An environmental and economic life cycle assessment of rooftop greenhouse (RTG) implementation in Barcelona, Spain. Assessing new forms of urban agriculture from the greenhouse structure to the final product level. Int. J. Life Cycle Assess. 20, 350-366. https://doi.org/10.1007/s11367-014-0836-9

Schmutz, U., Kneafsey, M., Sarrouy Kay, C., Doernberg, A., Zasada, I., 2017. Sustainability impact assessments of different urban short food supply chains: examples from London, UK. Renew. Agric. Food Syst. 1-11. https://doi.org/10.1017/S1742170517000564

Shiina, T., Hosokawa, D., Roy, P., Nakamura, N., Thammawong, M., Orikasa, T., 2011. Life cycle inventory analysis of leafy vegetables grown in two types of plant factories, in: Acta Horticulturae. International Society for Horticultural Science (ISHS), Leuven, Belgium, pp. 115-122.

https://doi.org/10.17660/ActaHortic.2011.919.14

Shinohara, M., Aoyama, C., Fujiwara, K., Watanabe, A., Ohmori, H., Uehara, Y., Takano, M., 2011. Microbial 
mineralization of organic nitrogen into nitrate to allow the use of organic fertilizer in hydroponics. Soil Sci. Plant Nutr. 57, 190-203. https://doi.org/10.1080/00380768.2011.554223

Singh, A., Singh, G.S., 2017. Vermicomposting: A sustainable tool for environmental equilibria. Environ. Qual. Manag. 27, 23-40. https://doi.org/10.1002/tqem.21509

Sioen, G.B., Sekiyama, M., Terada, T., Yokohari, M., 2017. Post-disaster food and nutrition from urban agriculture: A self-Sufficiency analysis of Nerima ward, Tokyo. Int. J. Environ. Res. Public Health 14, 120. https://doi.org/10.3390/ijerph14070748

Sioen, G.B., Terada, T., Sekiyama, M., Yokohari, M., 2018. Resilience with mixed agricultural and urban land uses in Tokyo, Japan. Sustain. 10, 1-27. https://doi.org/10.3390/su10020435

Specht, K., Sanyé-Mengual, E., 2017. Risks in urban rooftop agriculture: Assessing stakeholders' perceptions to ensure efficient policymaking. Environ. Sci. Policy 69, 13-21.

https://doi.org/10.1016/j.envsci.2016.12.001

Specht, K., Siebert, R., Hartmann, I., Freisinger, U.B., Sawicka, M., Werner, A., Thomaier, S., Henckel, D., Walk, H., Dierich, A., 2014. Urban agriculture of the future: An overview of sustainability aspects of food production in and on buildings. Agric. Human Values 31, 33-51. https://doi.org/10.1007/s10460013-9448-4

Specht, K., Weith, T., Swoboda, K., Siebert, R., 2016a. Socially acceptable urban agriculture businesses. Agron. Sustain. Dev. 36, 1-14. https://doi.org/10.1007/s13593-016-0355-0

Specht, K., Zoll, F., Siebert, R., 2016b. Application and evaluation of a participatory "open innovation" approach (ROIR): The case of introducing zero-acreage farming in Berlin. Landsc. Urban Plan. 151, 4554. https://doi.org/10.1016/j.landurbplan.2016.03.003

Stanhill, G., 1980. The energy cost of protected cropping: A comparison of six systems of tomato production. J. Agric. Eng. Res. 25, 145-154. https://doi.org/10.1016/0021-8634(80)90055-4

Stoknes, K., Scholwin, F., Krzesiński, W., Wojciechowska, E., Jasińska, A., 2016. Efficiency of a novel "Food to waste to food" system including anaerobic digestion of food waste and cultivation of vegetables on digestate in a bubble-insulated greenhouse. Waste Manag. 56, 466-476. https://doi.org/10.1016/j.wasman.2016.06.027

SUEZ, 2017. The Decoset Syndicate and SUEZ inaugurate the heating network in the Econotre eco-pole: the first tomato greenhouses heated by energy recovered from household waste [WWW Document]. URL https://www.suez.com/en/News/Press-Releases/Econotre (accessed 5.25.18).

Theurl, M.C., Haberl, H., Erb, K.H., Lindenthal, T., 2014. Contrasted greenhouse gas emissions from local versus long-range tomato production. Agron. Sustain. Dev. 34, 593-602. https://doi.org/10.1007/s13593-013-0171-8

Thomaier, S., Specht, K., Henckel, D., Dierich, A., Siebert, R., Freisinger, U.B., Sawicka, M., 2015. Farming in and on urban buildings: Present practice and specific novelties of Zero-Acreage Farming (ZFarming). Renew. Agric. Food Syst. 30, 43-54. https://doi.org/10.1017/S1742170514000143

Tilman, D., Clark, M., 2014. Global diets link environmental sustainability and human health. Nature 515, 518-522. https://doi.org/10.1038/nature13959

Tolksdorf, J., Lu, D., Cornel, P., 2016. First implementation of a SEMIZENTRAL resource recovery center. J. Water Reuse Desalin. 6, 466-475. https://doi.org/10.2166/wrd.2016.129

Tomasi, N., Pinton, R., Dalla Costa, L., Cortella, G., Terzano, R., Mimmo, T., Scampicchio, M., Cesco, S., 2014. New "solutions" for floating cultivation system of ready-to-eat salad: A review. Trends Food Sci. Technol. 46, 267-276. https://doi.org/10.1016/j.tifs.2015.08.004

Tornaghi, C., 2014. Critical geography of urban agriculture. Prog. Hum. Geogr. 38, 551-567. https://doi.org/10.1177/0309132513512542

Touliatos, D., Dodd, I.C., Mcainsh, M., 2016. Vertical farming increases lettuce yield per unit area compared to conventional horizontal hydroponics. Food Energy Secur. 5, 184-191. https://doi.org/10.1002/fes3.83

UNCCD, 2017. Global Land Outlook. https://doi.org/ISBN: 978-92-95110-48-9

UNICEF, 2016. Global Nutrition Report 2016 From Promise to Impact Ending Malnutrition by 2030 Summary. https://doi.org/10.2499/9780896299948 
van Huis, A., 2013. Potential of Insects as Food and Feed in Assuring Food Security. Annu. Rev. Entomol. 58, 563-583. https://doi.org/10.1146/annurev-ento-120811-153704

Walker, M., Theaker, H., Yaman, R., Poggio, D., Nimmo, W., Bywater, A., Blanch, G., Pourkashanian, M., 2017. Assessment of micro-scale anaerobic digestion for management of urban organic waste: $A$ case study in London, UK. Waste Manag. 61, 258-268. https://doi.org/10.1016/j.wasman.2017.01.036

Weber, C.L., Matthews, H.S., 2008. Food-Miles and the Relative Climate Impacts of Food Choices in the United States. Environ. Sci. Technol. 42, 3508-3513.

Weithmann, N., Möller, J.N., Löder, M.G.J., Piehl, S., Laforsch, C., Freitag, R., 2018. Organic fertilizer as a vehicle for the entry of microplastic into the environment. Sci. Adv. 4, 1-8. https://doi.org/10.1126/sciadv.aap8060

WHO, 2003. Diet, nutrition and the prevention of chronic diseases. WHO Technical Report Series, No. 916 (TRS 916). Rome.

Wielemaker, R.C., Weijma, J., Zeeman, G., 2018. Harvest to harvest: Recovering nutrients with New Sanitation systems for reuse in Urban Agriculture. Resour. Conserv. Recycl. 128, 426-437. https://doi.org/10.1016/j.resconrec.2016.09.015

Wilhelm, J.A., Smith, R.G., 2017. Ecosystem services and land sparing potential of urban and peri-urban agriculture: A review. Renew. Agric. Food Syst. 1-14. https://doi.org/10.1017/S1742170517000205

Wilkins, J.L., Farrell, T.J., Rangarajan, A., 2015. Linking vegetable preferences, health and local food systems through community-supported agriculture. Public Health Nutr. 18, 2392-2401. https://doi.org/10.1017/S1368980015000713

Wise, J., 2017. The Challenges behind Insect Farming in the UK, in: Farming Insects in the UK Conference. ADAS, London.

Wortman, S.E., Lovell, S.T., 2013. Environmental Challenges Threatening the Growth of Urban Agriculture in the United States. J. Environ. Qual. 42, 1283. https://doi.org/10.2134/jeq2013.01.0031

Zhang, S., Bi, X.T., Clift, R., 2013. A Life Cycle Assessment of integrated dairy farm-greenhouse systems in British Columbia. Bioresour. Technol. 150, 496-505. https://doi.org/10.1016/j.biortech.2013.09.076 